\title{
Leverage Points for Governing Agricultural Soils: A Review of Empirical Studies of European Farmers' Decision-Making
}

\author{
Bartosz Bartkowski * (D) and Stephan Bartke \\ Department of Economics, UFZ-Helmholtz Centre for Environmental Research, 04318 Leipzig, Germany; \\ stephan.bartke@ufz.de \\ * Correspondence: bartosz.bartkowski@ufz.de; Tel.: +49-341-235-1690
}

Received: 30 May 2018; Accepted: 31 August 2018; Published: 5 September 2018

\begin{abstract}
What drives farmers' decision-making? To inform effective, efficient, and legitimate governance of agricultural soils, it is important to understand the behaviour of those who manage the fields. This article contributes to the assessment and development of innovative soil governance instruments by outlining a comprehensive understanding of the determinants of farmers' behaviour and decision-making. Our analysis synthesises empirical literature from different disciplines spanning the last four decades on various farm-level decision-making problems. Based on a conceptual framework that links objective characteristics of the farm and the farmer with behavioural characteristics, social-institutional environment, economic constraints, and decision characteristics, empirical findings from 87 European studies are presented and discussed. We point out that economic constraints and incentives are very important, but that other factors also have significant effects, in particular pro-environmental attitudes, goodness of fit, and past experience. Conversely, we find mixed results for demographic factors and symbolic capital. A number of potentially highly relevant yet understudied factors for soil governance are identified, including adoption of technologies, advisory services, bureaucratic load, risk aversion and social capital, social norms, and peer orientation. Our results emphasise the importance of a broad behavioural perspective to improve the efficiency, effectiveness, and legitimacy of soil governance.
\end{abstract}

Keywords: agricultural policy; behavioural studies; literature review; soil functions; soil pressures

\section{Introduction}

Despite seed banks, in vitro meat production, hydroponic farming, or vertical greening, soils continue to be the essential basis for human health and well-being. They are not only indispensable for the provision of food, feed, fuel, and fibre; soil functions are also critical for water storage and filtration, carbon sequestration and storage, support of infrastructure, etc. [1,2]. In fact, most terrestrial ecosystem services are dependent on functioning soils, which provide many-often not recognised-benefits to people. However, soils are globally threatened by multifaceted processes of degradation [3,4]. Policies are needed for the effective protection of soils and their efficient use. Yet, current governance regimes are deficient in terms of protecting soils and ensuring their sustainable management [5-7]. To improve this situation, society is in need of (i) a thorough understanding of the drivers of soil degradation [8] and the societal impacts of soil management [9] so as to be able to properly assess the relevant trade-offs; (ii) an equally encompassing understanding of the processes within the soil that give rise to soil functions and ecosystem services and how they are affected by soil management [10]; and (iii) innovative governance instruments building upon a comprehensive understanding of the determinants of relevant actors' behaviour and decision-making. 
Although optimal governance would be based on knowledge regarding all three factors, in the absence of information on (i) and (ii), a second-best approach to inform governance under incomplete information is necessary as farmers make day-to-day decisions. Here, we focus on disentangling the decision-making determinants. Of course, questions to challenges (i) and (ii) are sought in research projects around the world; available results can be combined with our analysis to inform soil policy.

Agriculture is one of the most prominent and direct interfaces between human activity and soils. We are all consumers of agricultural products and, thus, (highly dependent) beneficiaries of the use of soil as a resource. Agricultural soils are both a private good and a public good. The group that most directly interacts and influences soils-both in subsistence economies of the global South and in industrialised countries of the global North-is farmers. Therefore, it is inevitable to look at farmers and their land-use practices when the goal is to identify ways and means to make soil management more sustainable through proper soil governance instruments. In other words, the determinants of farmers' behaviour and decision-making regarding soil management can be regarded as leverage points for soil governance, i.e., areas for easy interventions that can result in potential significant changes [11,12]; however, 'there is no precise assessment on how the existing policies have affected, and will further impact, the pressure on agricultural soils in Europe. Such assessment would require knowledge on [ ... ] how farmers' soil management responds to policy measures, and [ ... ] what impact these responses have on the state of soils in short and longer term' [13] (p. 241, emphasis added). Our key question is therefore: Which factors do European farmers respond to in their decision-making? What influences their behaviour related to soil management?

There exist a large number of empirical studies into these questions and a small number of synthesising studies with a focus similar to our research question. For instance, in an influential and widely cited large-scale study, Wilson and Hart [14] tried to disentangle economic from non-economic factors that influence participation in agri-environmental schemes (AESs) in the European Union (E.U.). Siebert and colleagues [15] synthesised a large corpus of empirical literature (including grey literature) investigating European farmers' participation in biodiversity policies, finding that financial incentives are important but not the only relevant factor that makes farmers participate. Lastra-Bravo et al. [16] conducted a meta-analysis of discrete choice experiment studies investigating drivers of farmers' participation in E.U. AESs, identifying economic and demographic factors as important influences in this context. In the specific context of soil conservation, an important though older review study is by Prager and Posthumus [17]. They used a theoretical framework inspired by innovation adoption research to synthesise empirical insights with a specific focus on adoption of soil conservation. As such, our paper can be viewed as extending and updating the knowledge generated in their study. Riley [18] synthesised the literature on farmers' participation in AESs mainly from a sociological and human geographic perspective, focusing on changes in farmers' attitudes and cultures due to AES participation. Burton [19] focused on the causal explanations of links between demographic variables (age, experience, education, and gender) and farmers' 'environmental behaviour'. In a recent study, Liu and colleagues [20] synthesised post-2008 applied economic research on the factors influencing farmer adoption of best management practices (BMP), with a particular focus on water pollution. Their study is an update of earlier studies by Knowler and Bradshaw [21] and Prokopy et al. [22]. All three studies had either a global scope or a U.S. focus. Liu et al. note that '[t]he majority of case studies [they] reviewed were [conducted] in the U.S. and Australia' (p. 3). Generally, it can be said that most existing literature reviews and syntheses had a narrow thematic and/or disciplinary focus, while usually having a broad geographical scope. In our study, the geographical scope is comparatively narrow, as we think that it is more sensible to keep the cultural and legal context relatively constant across analysed studies, particularly when the ultimate aim is to derive implications for soil governance in a specific cultural-political context. Conversely, our thematic and disciplinary foci are broad, which reflects the recognition that (i) soil management is influenced by many different decisions made by farmers, directly and indirectly; and (ii) the combination of different disciplinary perspectives can be very fruitful, as impressively shown by recent advances in 
behavioural research [23] and requested in the recent agenda for strategic research on land use and soil management in Europe [24].

Thus, our analysis differs from those attempts mentioned above in two ways: first, it synthesises empirical literature of various farm-level decision-making problems analysed from the perspective of different disciplines (including economics, social psychology, sociology, and human geography) with a geographical focus on the European Union and spanning the last four decades, noting that there has been a strong increase in publication numbers in this area in the last decade or so. Second, we use these insights to identify leverage points that will support the formulation of effective and efficient governance instruments aiming at sustainable management of agricultural soils. However, even though the focus is on agricultural soil management, the results have wider applicability to agri-environmental and natural resource policies.

We start in the next section by presenting the conceptual framework that will guide our analysis of the literature. Subsequently, in Section 3, we briefly discuss data and methods used for the literature review of empirical studies of E.U. farmers' behaviour. In Section 4, we present the results of the literature review, which are discussed in Section 5, where we point out particularly interesting results and put them into a broader perspective. In Section 6, we derive implications for governance of agricultural soils. Section 7 concludes.

\section{Conceptual Framework}

If we assumed that, agriculturally, used soils are merely a private good, thus focusing exclusively on their relevance for the production of food, feed, fibre, and fuel, and if we adopted the perspective of a hypothetical, naïve neoclassical economist, then there would be no need for explicit soil governance beyond the pure market mechanism. In such a simplified model, the rational farmer chooses an optimal soil management strategy so as to maximise the net present value of the stream of future income she derives from agricultural production. The factors relevant for decision-making are market prices of inputs and agricultural products. In this model, there are no soil-related externalities, information is either perfect or at least available at a calculable cost, and the future is deterministic. Of course, this model is too simple; however, it helps to identify the reasons why we need soil governance and why we need a more sophisticated model of farmers' decision-making (A first step would be, in order to make the model more realistic, to include as constraints existing regulations and non-market incentives, such as the Common Agricultural Policy (CAP) of the E.U. Most of them, however, are at best only loosely considering soils in an explicit manner [5]).

Farmers' decision-making has frequently been viewed through the lens of a simplistic behavioural model inspired by rational choice theory $[25,26]$. However, while economic motives are highly relevant for farmers' decision-making [14], a complex web of other factors also plays a role [26,27]. An overly narrow focus on economic factors involves the risk of ineffective or inefficient policies: governance instruments differ in terms of transaction costs, efficiency, and 'intrusion' into farmers' (or consumers') freedom of choice. Sometimes indirect, for example persuasive, approaches may be more effective (for instance influencing the image of a 'good farmer' [28]), but to apply those with efficacy, one needs a sound understanding of decision-making factors beyond purely economic considerations. Furthermore, an exclusive focus on economic motivation favours incentive-based policy instruments to influence behaviour; however, the necessary compensation payments (or, in economic terms, farmers' minimum willingness to accept compensation) may well be influenced by non-economic obstacles (for instance cultural factors); efficiency of such policy schemes may be increased by including and targeting other factors rather than simply increasing payments. Thus, in an ideal analysis all relevant factors that likely influence on-farm decision-making need to be taken into account. A realisation of this ideal is neither realistic nor necessary. However, behavioural research shows that increasing the complexity of behavioural models underlying environmental policies can increase their effectiveness and efficiency [23]. Therefore, we want to contribute to systematic analysis of available information about farmers' decision-making. 
Figure 1 presents our conceptual framework for the analysis of the corpus of literature. It is assumed here that farmers' decision-making is influenced by six general groups of factors:

- 'objective' characteristics of the farm, including farm size, local environmental conditions, and technological facilities;

- 'objective' characteristics of the farmer, i.e., mainly demographic factors, such as age, education, gender, and household size;

- behavioural characteristics of the farmer, i.e., her attitudes, awareness, knowledge, beliefs, and perceptions;

- social-institutional environment, i.e., the external factors related to legal and institutional frameworks the farmer is faced with as well as her peers;

- economic constraints, i.e., the immediate economic pressures, such as availability of credit, cost of measures, etc. faced by the farmer as well as financial incentives and compensation payments;

- decision characteristics, i.e., factors that are inherently related to the specific decision, including the 'goodness of fit' [29] of the decision with the overall activities of the farmer, including the fit with existing legal restrictions.

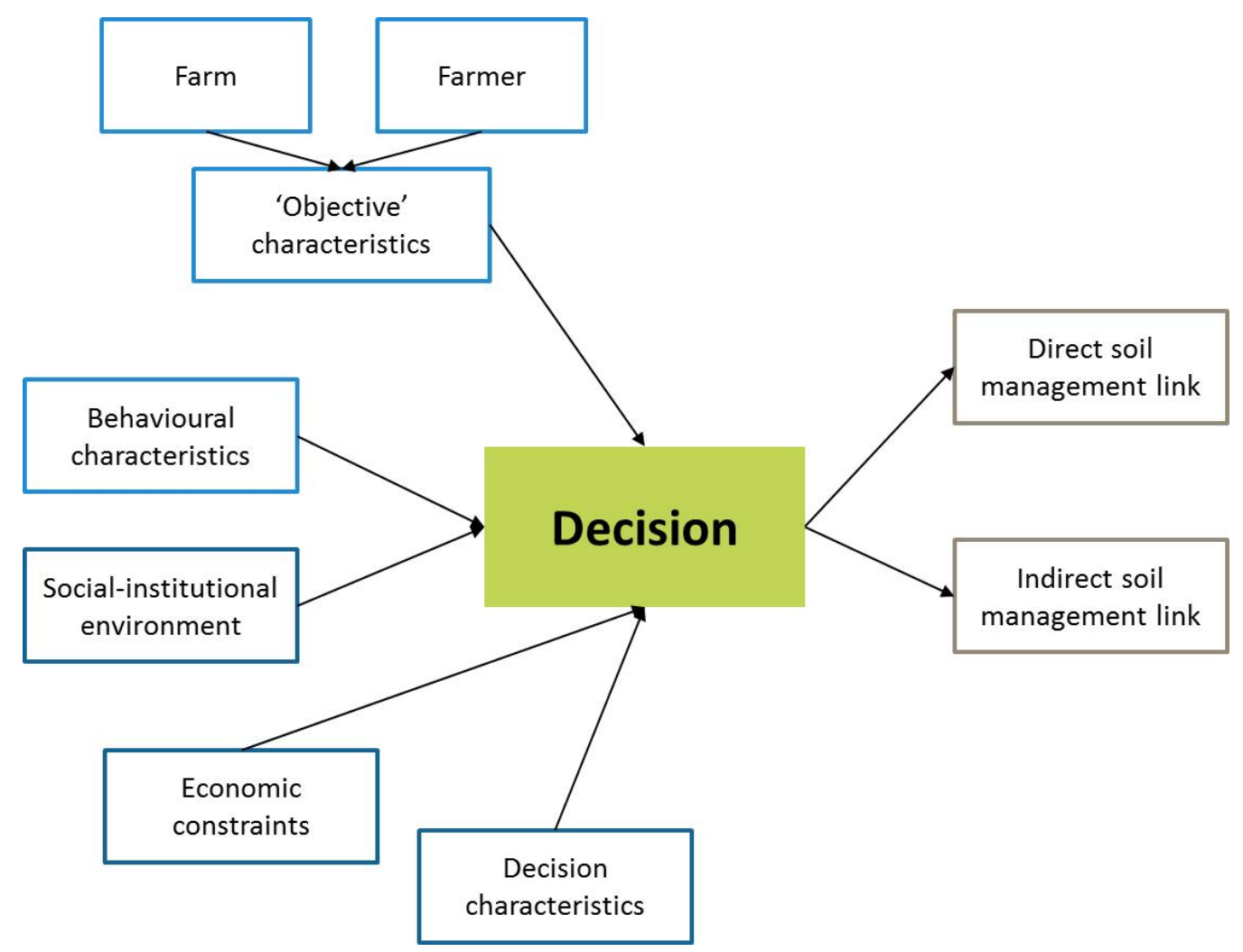

Figure 1. Conceptual framework of farmers' decision-making related to soil management.

The first three categories can be considered internal factors, which describe the decision-making farmer and do not vary across decisions; the latter three are external factors, which may vary across decisions, though to different extent (increasing in the order they are listed above) [30]. Of course, it is not always possible to clearly distinguish between those categories and there are overlaps. This part of the framework bears some superficial similarity with the basic conceptual framework of the Theory of Planned Behaviour [31]. However, it is kept more general and interpretationally flexible so as to do justice to the vast diversity of theoretical approaches underlying the studies included in our review, only some of which are based on the Theory of Planned Behaviour. Similar 
frameworks in a related context can be found for example in Greiner and Gregg's [32] study on the adoption of conservation practices by Australian farmers or in the above-mentioned review by Liu et al. [20]. Furthermore, the framework has been developed iteratively so as to fit the range of factors (decision-making determinants) identified in the literature reviewed here. The right-hand part of the framework presented in Figure 1 refers to the link between different decisions made by farmers and soil management. In some cases, this link may be quite direct; for instance, when the decision regards ploughing or fertilisation. In other cases, however, the link may be rather indirect; for example, when the decision is about which type of tractor to buy. This framework will guide the analysis of the empirical literature surveyed here.

\section{Data and Methods}

\subsection{Literature Review}

The literature review has the aim to identify a comprehensive selection of empirical studies investigating factors that influence the decision-making of farmers in European countries. Due to the heterogeneity of the reviewed literature and workload constraints, we refrained from conducting a fully comprehensive systematic literature review. However, comparison with earlier reviews focusing on specific decision types (see Section 1) suggests that our selection is fairly representative and captures the largest part of the literature. Pragmatic considerations dictated geographic restrictions; we decided for the E.U. and neighbouring countries (particularly Switzerland) due to their common political, economic, and cultural background (the search also included all European countries except Russia and small states, such as San Marino or Andorra; however, no studies were found nor included from outside the E.U. and Switzerland). A combination of keywords (see Appendix A) was used to identify studies that match the three basic criteria: empirical studies (i) focusing on farmers' decision-making (ii) in Europe (iii). The search string was applied to the Web of Science (All databases); all articles indexed by 10 September 2017 were included. A total of 308 publications matching the combination search terms was detected. In a second step, their abstracts were screened to exclude those that are not relevant for the purposes of this review. Reasons for exclusion and the frequency of their application in the screening process are listed in Table 1.

Table 1. Number of excluded papers by exclusion criterion.

\begin{tabular}{cc}
\hline Exclusion Criterion & Number of Excluded Papers \\
\hline Human/animal health/welfare & 73 \\
Non-European & 64 \\
No decision-making focus & 24 \\
Not empirical & 8 \\
Decisions clearly without link to soils & 5 \\
Covered in earlier publication(s) & 5 \\
Others (non-English, biology ... ) & 12 \\
\hline
\end{tabular}

The application of the exclusion criteria to the abstracts reduced the number of relevant studies to 117; of those, 3 were not accessible. The remaining 114 studies were then subjected to full-text analysis; during this process, another 27 studies were found to be irrelevant so that the final analysis is based on a total of 87 studies. Table 2 summarises the information extracted and coded from the publications included in the literature review. In addition to matching behavioural factors with the categories of the conceptual framework, we follow Floress et al. [33] in distinguishing between actual decisions ('behavior' in their nomenclature) and hypothetical decisions ('willingness or intent'). Where possible, we linked the decision-making problem to soil pressures based on Vogel et al. [10]: tillage, crop rotation, fertilization, pest control, irrigation, and compaction/traffic. Both decision types and influencing factors were grouped into generic categories for the purposes of further analysis. 
Table 2. Description of information extracted from reviewed studies.

\begin{tabular}{|c|c|c|}
\hline Category & Explanation & Data Type \\
\hline \multicolumn{3}{|c|}{ Publication Description } \\
\hline ID & $\begin{array}{l}\text { Running number for each study, in chronological order according to } \\
\text { Web of Science }\end{array}$ & Integer \\
\hline Authors & Authors of the study (short) & Text \\
\hline Year & Year of publication & Integer \\
\hline Title & Title of publication & Text \\
\hline Journal & Journal of publication & Text \\
\hline DOI & Digital Object Identifier (if available) & Text \\
\hline \multicolumn{3}{|c|}{ Decision Context } \\
\hline Production type & Type of agricultural production (livestock, food, biomass, multiple *) & Category \\
\hline Production type specific & Specification of 'Production type' & Text \\
\hline Agriculture type & Type of agriculture (conventional, organic, multiple *) & Category \\
\hline Soil pressure & Soil pressure type related to the decision studied, if applicable & Category \\
\hline Region & Region of study according to publication & Text \\
\hline Country code & ISO 3166-1 Alpha-2 code & Category \\
\hline Time period & Time when study was conducted according to publication & Integer (ranges) \\
\hline Year & Latest year of 'Time period' & Integer \\
\hline Sample size & Number of farmers or farms studied & Integer \\
\hline Remarks & Additional remarks pertaining to study & Text \\
\hline \multicolumn{3}{|c|}{ Behavioural Factors } \\
\hline Method & Method applied in study & Category \\
\hline Theoretical background & Theoretical background of study (if explicitly mentioned) & Category \\
\hline Inductive & $\begin{array}{l}\text { Decision-making factors identified in study were inductively derived } \\
\text { (versus: were preformulated as hypothesis, i.e., deductive) }\end{array}$ & YES/NO \\
\hline Justification of relevance & $\begin{array}{l}\text { Explicit relation to a specific societal challenge (e.g., sustainability, } \\
\text { climate change, bioeconomy) }\end{array}$ & Category \\
\hline Factor & Individual decision-making factor (generalised where possible) & Category \\
\hline Framework category & Relation of the factor to a category of the conceptual framework & Category \\
\hline Significant & Statistical significance of the factor in study, if applicable & YES/NO \\
\hline Decision type specific & Type of decision analysed in study & Text \\
\hline Decision type & Categorised type of decision & Category \\
\hline Actual decision & $\begin{array}{l}\text { Decision analysed was actual (behaviour) versus hypothetical } \\
\text { (intention/willingness) }\end{array}$ & YES/NO \\
\hline Direction of influence & $\begin{array}{l}\text { Factor facilitating ('positive') or counteracting ('negative') behaviour } \\
\text { under study, if applicable }\end{array}$ & Positive/negative \\
\hline Remarks & $\begin{array}{l}\text { Further information about the factor or its link to decision, incl. } \\
\text { specification of 'Factor' where necessary }\end{array}$ & Text \\
\hline
\end{tabular}

Except for some descriptive statistics, the analysis of the 87 empirical studies is largely qualitative, other than, for example, Prokopy et al.'s [22] meta-analysis of the determinants of agricultural best management practices. The reasons for this are twofold. First, many of the studies analysed are themselves qualitative and little or no quantitative data pertaining to the question at hand could be derived from them. Second, the range of types of analysis in terms of disciplinary and theoretical background is very large, which means that a qualitative synthesis is more sensible. This means that it 
is impossible, on the basis of our analysis, to estimate the relative strength of the different factors in determining decision-making behaviour.

\subsection{Bibliometric Analysis}

Because of the diversity of the literature reviewed, it is worthwhile to review general patterns that connect or divide this body of literature. For such purposes, tools of bibliometric analysis are useful. In this paper, we use VOSviewer, Leiden University, The Netherlands [34] to visualise some basic patterns of relationship among the publications included in our review. The visualisations are based on the 'full records and citations' from Web of Science for all 87 reviewed publications.

\section{Literature Review Results}

\subsection{Bibliometric Results}

The choice of journals can be used as an indicator of the disciplinary background of studies. In total, articles from 48 different journals entered our survey. As can be seen in Figure 2, the most widely represented journals (with at least two articles in the review) include interdisciplinary (Land Use Policy, Journal of Environmental Management, Agricultural Systems, Journal of Environmental Planning and Management, Outlook on Agriculture, to some extent also Ecological Economics), economic (Journal of Agricultural Economics, Ecological Economics, Agricultural Economics-Czech), sociological (Journal of Rural Studies, Sociologia Ruralis), and applied ethics (Agriculture and Human Values) journals. The large category of 'others' contains further journals from above-mentioned disciplines, but also from agronomy, ecology, geography, management, and psychology.

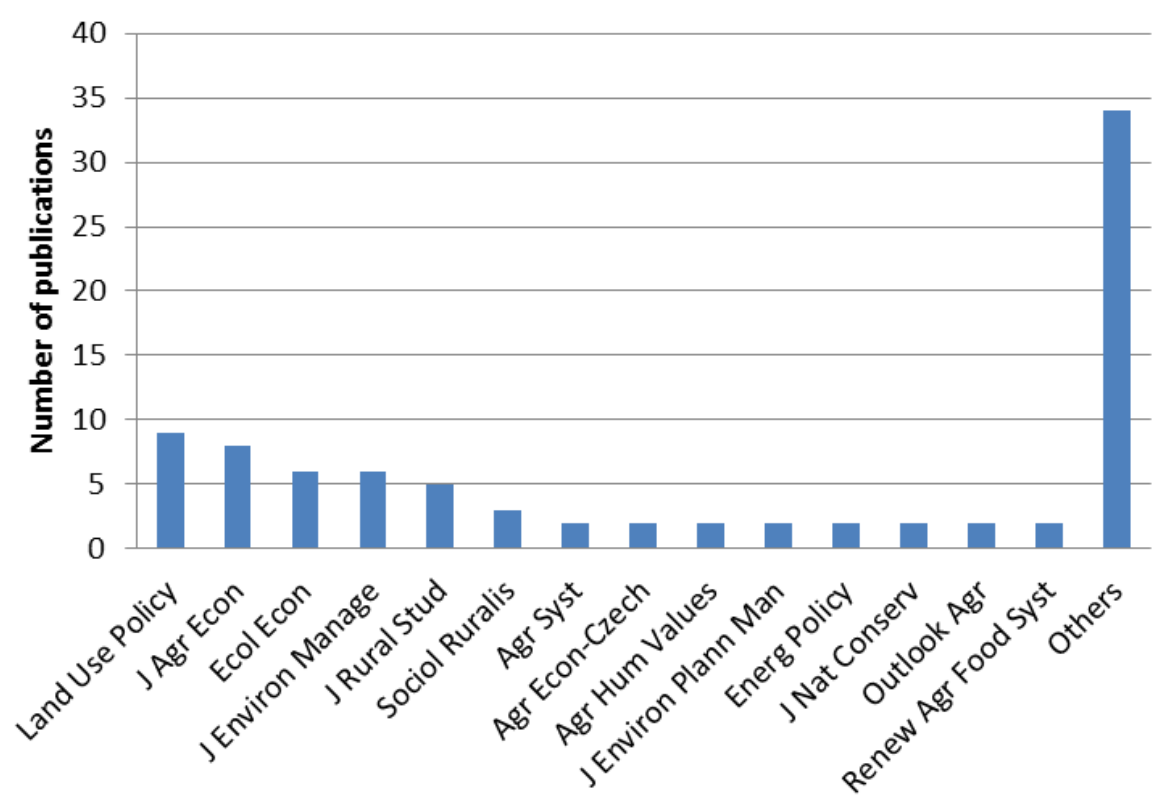

Figure 2. Distribution of publications across journals.

Despite this disciplinary diversity, there are many bibliographic links within the reviewed body of literature (Figure 3). The most widely cited study is Morris and Potter's [35] pioneering analysis of the adoption of AESs by U.K. farmers (15 citations within the reviewed corpus). The colours in Figure 3 indicate clusters identified by VOSviewer on the basis of cross- and co-citations [36]: the red cluster consists mainly of discrete choice experiments (CE) on AES participation; the dark blue cluster are predominantly economic (but non-CE) studies of AES participation, while sociological studies with the same (AES) focus form the green cluster. 


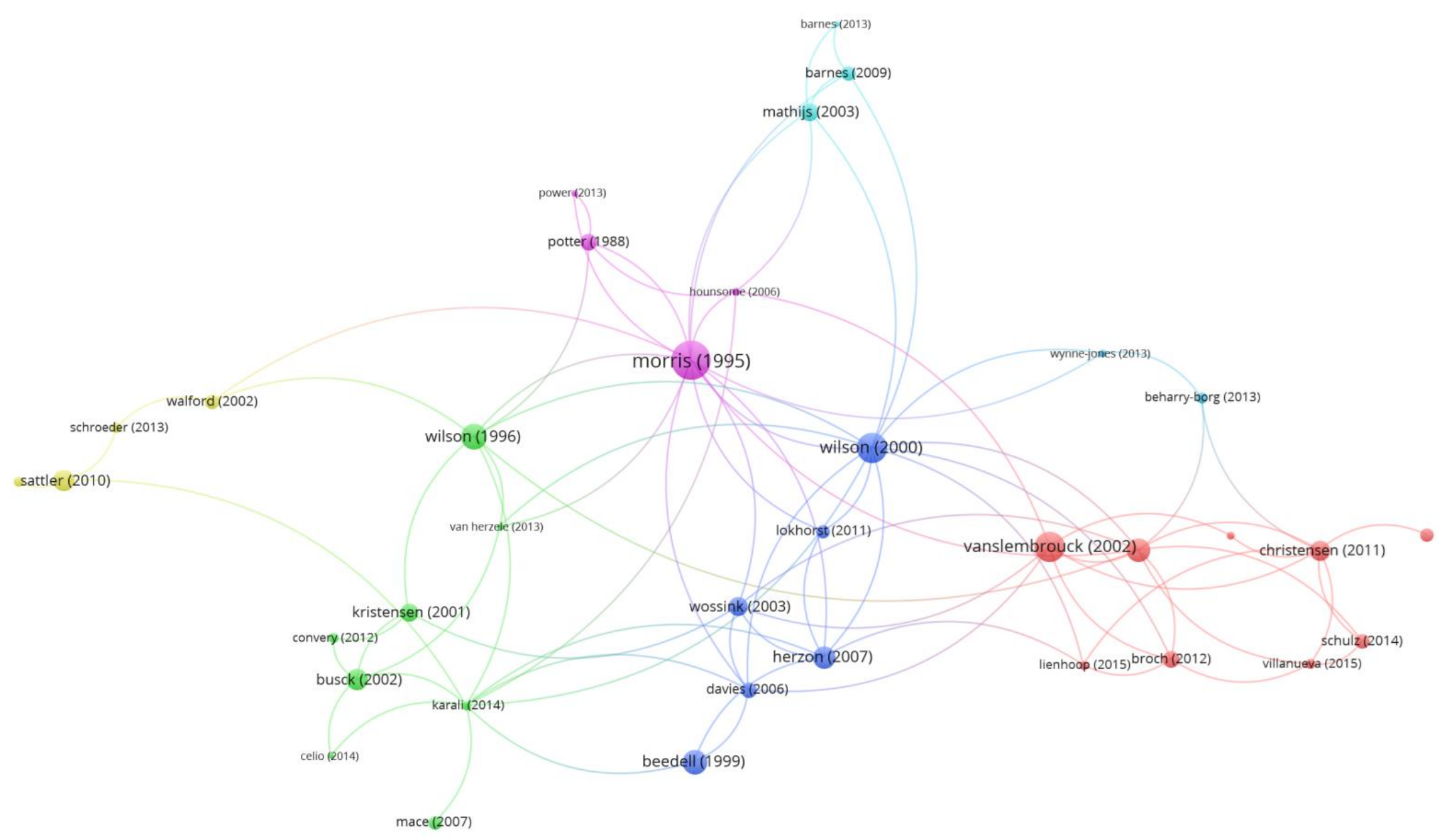

Figure 3. Cross-citations between publications included in review. 


\subsection{Descriptive Results}

In this section, the main descriptive results of the review are summarised. With respect to the geographic distribution of the studies analysed, most were conducted in the large E.U. countries U.K., Germany, France, Spain, and Italy; among the smaller countries, Denmark, Greece, Belgium, Sweden, and The Netherlands are particularly well-represented (Figure 4). It is striking that eastern E.U. member states are heavily under-represented in this literature, despite of or maybe due to their relatively late accession to the E.U., offering an interesting context for decision-making analysis.

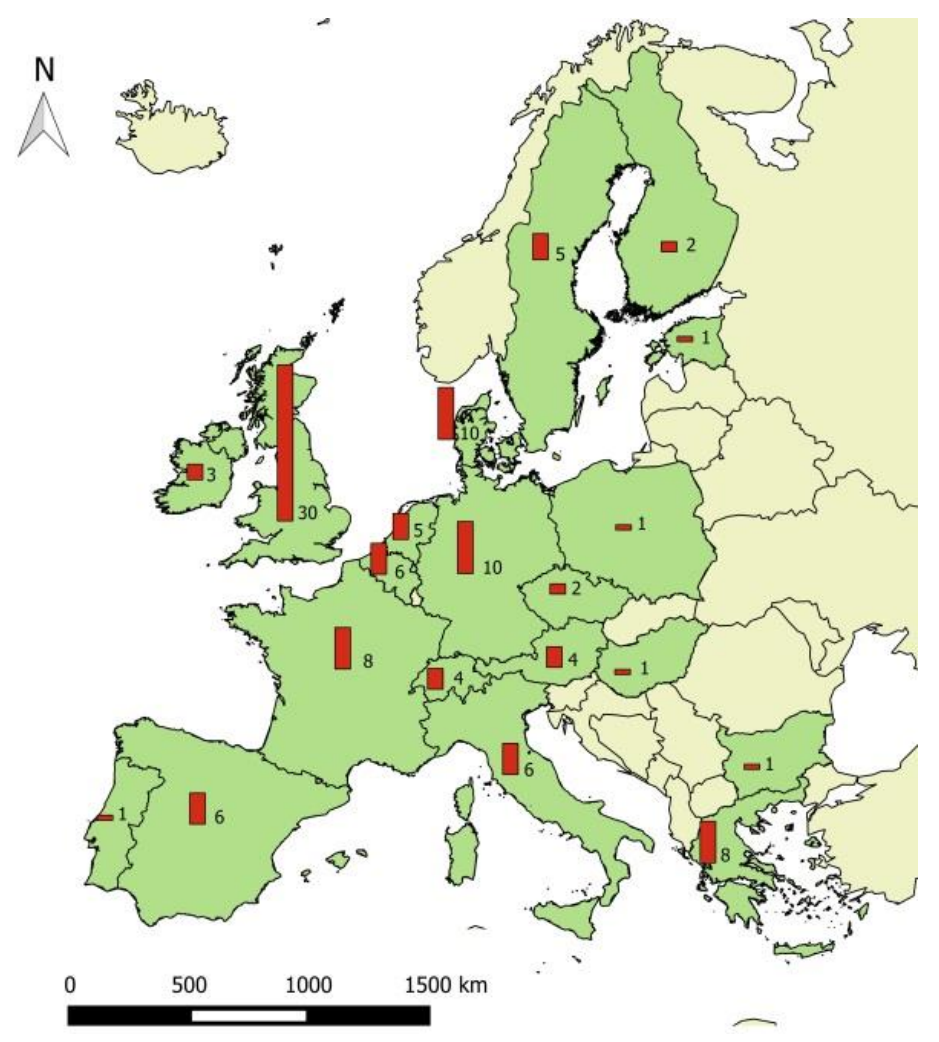

Figure 4. Distribution of studies across countries.

Most studies included in the review were conducted and published post-2008 (Figure 5); for 23 studies, no time frame was reported.

Table 3 matches categories of the conceptual framework with factors (decision-making determinants) identified in the review. It mainly illustrates the diversity of factors within each category and not the frequency with which each category was present in the studies analysed, as some factors were analysed only once or twice, while others were analysed in multiple studies each. The most frequently analysed factors were: economic considerations (analysed 55 times), pro-environmental attitude (36), age (34), education (28), farm size (27), entrepreneurial attitudes (21), perception of the problem (20), symbolic capital (18) (note that the term symbolic capital is used rather loosely here and does not correspond perfectly to its more specific use in the Bourdieu-inspired literature $[29,37,38]$; rather, here it encompasses all notions of perception by others, be it peers or customers or the general society), income-dependency on farm (16), and past experience (16). Note that some studies analysed some factors in more than one variant; for example, economic considerations were studied in 47 studies, but those generated 55 results for this factor. 


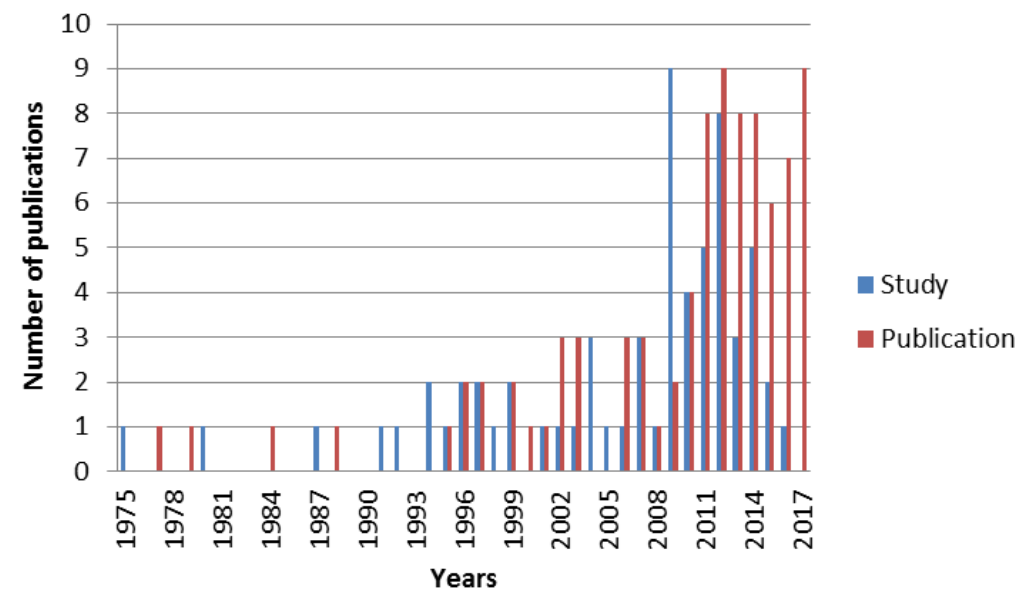

Figure 5. Temporal distribution of studies.

Table 3. Factors identified in review and framework categories.

\begin{tabular}{clc}
\hline Framework Categories & \multicolumn{1}{c}{ Factors Identified in Review } & \# \\
\hline Objective characteristics of farm & $\begin{array}{l}\text { Accessibility of parcels, availability of resources, environmental } \\
\text { conditions, farm diversification, farm location, farm profitability, farm } \\
\text { size, on-farm technologies, own land of special interest, reduction } \\
\text { farm activities, share of non-family labour, successorship, tenure, type } \\
\text { of agriculture, var. farm characteristics, yield }\end{array}$ & 86 \\
\hline \multirow{2}{*}{ Objective characteristics of farmer } & $\begin{array}{l}\text { Age, agricultural training, education, farming experience, gender, } \\
\text { health, household size, income, income-dependency on farm, marital } \\
\text { status, parent, past experience, path dependency, previous training }\end{array}$ & 125 \\
\hline Behavioural characteristics & $\begin{array}{l}\text { Attitude towards regulatory framework, awareness, beliefs, } \\
\text { conservativeness, entrepreneurial attitudes, environmental awareness, } \\
\text { general attitudes, identity, knowledge, lifestyle, loss aversion, peer } \\
\text { orientation, perception of the problem, pro-environmental attitude, } \\
\text { risk aversion, satisfaction, situational stress, symbolic capital, trust, } \\
\text { values, vocation }\end{array}$ & 159 \\
\hline Social-institutional environment & $\begin{array}{l}\text { Advisory services, availability of information, } \\
\text { dealers/representatives, local authorities, social capital, social norms }\end{array}$ & 32 \\
\hline Economic constraints & $\begin{array}{l}\text { Availability of credit, availability of labour, economic considerations, } \\
\text { financial stress }\end{array}$ & 59 \\
\hline Decision characteristics & $\begin{array}{l}\text { Availability of advice, availability of leisure, bureaucratic load, } \\
\text { collective participation, complexity of measure, context-specificity, } \\
\text { contract length, contract specifications, measure efficacy, eligibility for } \\
\text { further funding, environmental effects of measure, fit with existing } \\
\text { legal restrictions, fit with existing practices, flexibility of contract, } \\
\text { investment needs, labour intensity, monitoring, product quality, } \\
\text { purpose of measure, self-employment }\end{array}$ & 74 \\
\hline
\end{tabular}

The factors listed in Table 3 have been analysed in the studies included in our review in a number of different decision-making contexts. Figure 6 depicts the frequency of decision types within the body of literature. The most frequent decision types are participation in AES, choice of management (for instance, choice of pest control measures, decision between mowing and grazing, timing of manuring), local conservation (non-AES adoption of environmentally friendly management), (adoption or abandonment of) organic farming, adaptation to climate change, and water use choices (for instance irrigation) (see also Table 4). 


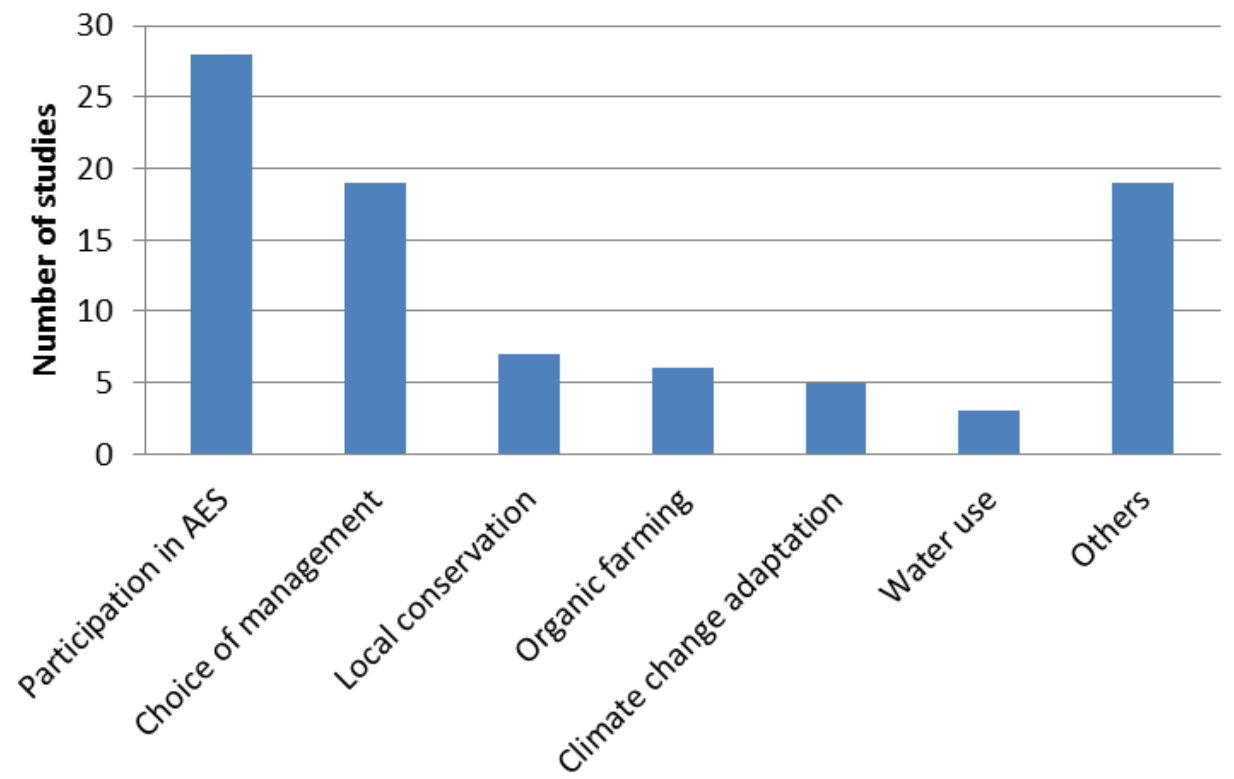

Figure 6. Frequency of decision types analysed across studies.

The decisions analysed in each study can be linked in some instances to soil pressures. The most frequent soil pressures are fertilization and pest control; however, since hardly any study had a specific focus on soil management, most decisions analysed had only an indirect link to soil and thus affected multiple soil pressures (Figure 7).

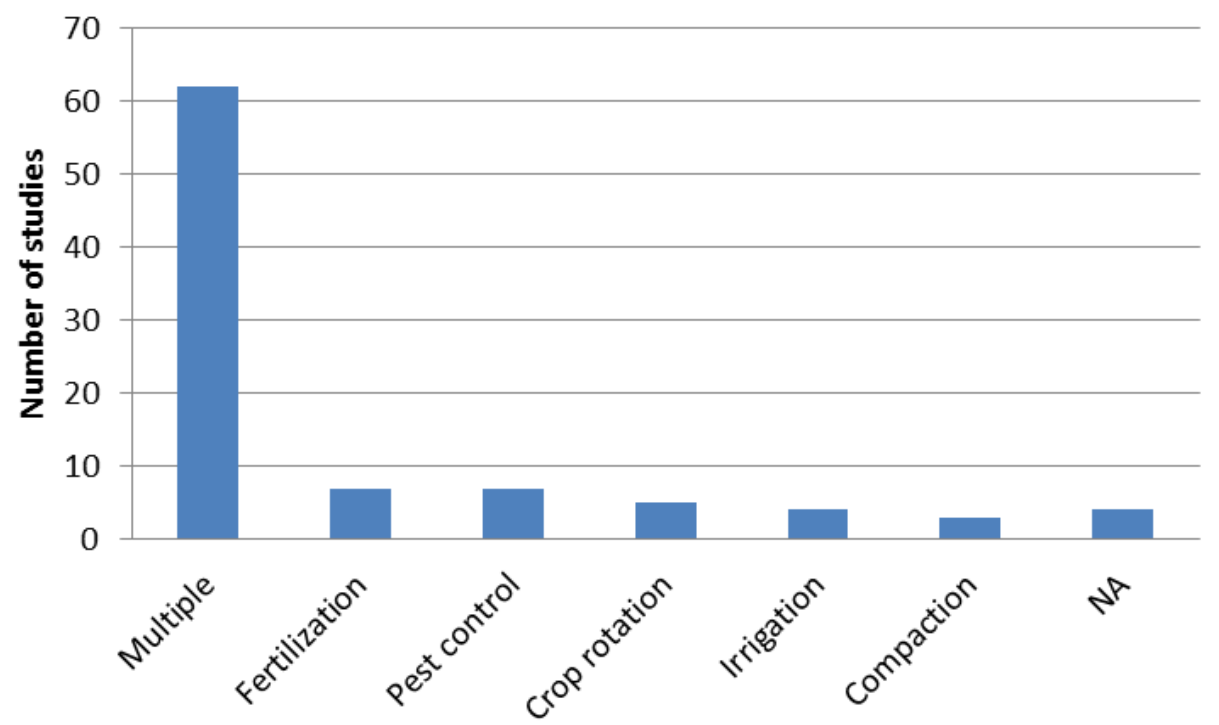

Figure 7. Soil pressures associated with analysed decisions.

Table 4 presents an overview of all decision types identified, the methods applied for each decision type, and the studies that analysed it. The frequency of each method class can be found in Figure A2 in Appendix B. In 54 studies, actual decisions were analysed, while 40 focused on hypothetical decisions (7 studies did both). 
Table 4. Overview of decision types, methods applied, and studies.

\begin{tabular}{|c|c|c|}
\hline Decision Type & Methods Applied & Studies \\
\hline $\begin{array}{l}\text { Adoption of renewable energy } \\
\text { production }\end{array}$ & $\begin{array}{l}\text { Questionnaire survey, interviews, } \\
\text { focus groups }\end{array}$ & $\begin{array}{l}\text { Convery et al. [40], Reise et al. [41], Tate et al. [42], } \\
\text { Warren et al. [43] }\end{array}$ \\
\hline Choice of management & $\begin{array}{l}\text { Questionnaire survey, interviews, } \\
\text { choice experiment, role-playing } \\
\text { game }\end{array}$ & $\begin{array}{l}\text { Bager and Proost [44], Mary et al. [45], Macé et al. [46], } \\
\text { Ingram [47], Barnes et al. [48], Wright and Jacobsen [49], } \\
\text { Papadopoulou [50], Sharma et al. [51], } \\
\text { Morgan-Davies et al. [52], Pedersen et al. [53], } \\
\text { Barnes et al. [54], Beharry-Borg et al. [55], } \\
\text { Karelakis et al. [56], Damalas and Koutroubas [57], Jaeck } \\
\text { and Lifran [58], Lamarque et al. [59], Bechini et al. [60], } \\
\text { Macgregor and Warren [61] }\end{array}$ \\
\hline Choice of machinery & Interviews & Foxall [62] \\
\hline Entering a new market & Interviews, questionnaire survey & Ambrosius et al. [70], Demartini et al. [71] \\
\hline Environmental behaviour & Questionnaire survey & Vogel [72] \\
\hline General decision-making & Questionnaire survey & Celio et al. [73] \\
\hline Illegal wildlife killing & Questionnaire survey & Cerri et al. [74] \\
\hline Investment decision & Internet-based experiment & Hermann et al. [75] \\
\hline Job change & Choice experiment & Lips et al. [76] \\
\hline Local conservation & Questionnaire survey, interviews & $\begin{array}{l}\text { Beedell and Rehman [77], Kristensen et al. [78], Busck [79], } \\
\text { Herzon and Mikk [80], Sattler and Nagel [81], } \\
\text { Lokhorst et al. [82], Mills et al. [83] }\end{array}$ \\
\hline Participation in cooperative & Interviews & Gasson [117] \\
\hline Participation in greening & Choice experiment & Schulz et al. [118] \\
\hline Risk management strategies & Questionnaire survey & van Winsen et al. [119] \\
\hline Specialisation & Interviews & Ilbery [120] \\
\hline Water use & $\begin{array}{l}\text { Contingent valuation, } \\
\text { questionnaire survey }\end{array}$ & $\begin{array}{l}\text { Menegaki et al. [121], Bakopoulou et al. [122], } \\
\text { Giannoccaro and Berbel [123] }\end{array}$ \\
\hline
\end{tabular}

Further results can be found in Appendix B.

\section{Discussion}

Given the large number of decision-making contexts, investigated factors, and methodological approaches, we will focus in the discussion on pointing out particularly strong results and particularly interesting ones (which, of course, will be based on a significant amount of subjective evaluation of which results are interesting) in the literature focused on European cases. However, Figure 8 provides a more general overview by highlighting the most frequently studied (considered in at least 9 publications, i.e., 10 or more percent of the overall 87 studies) decision-influencing factors and their significance. 


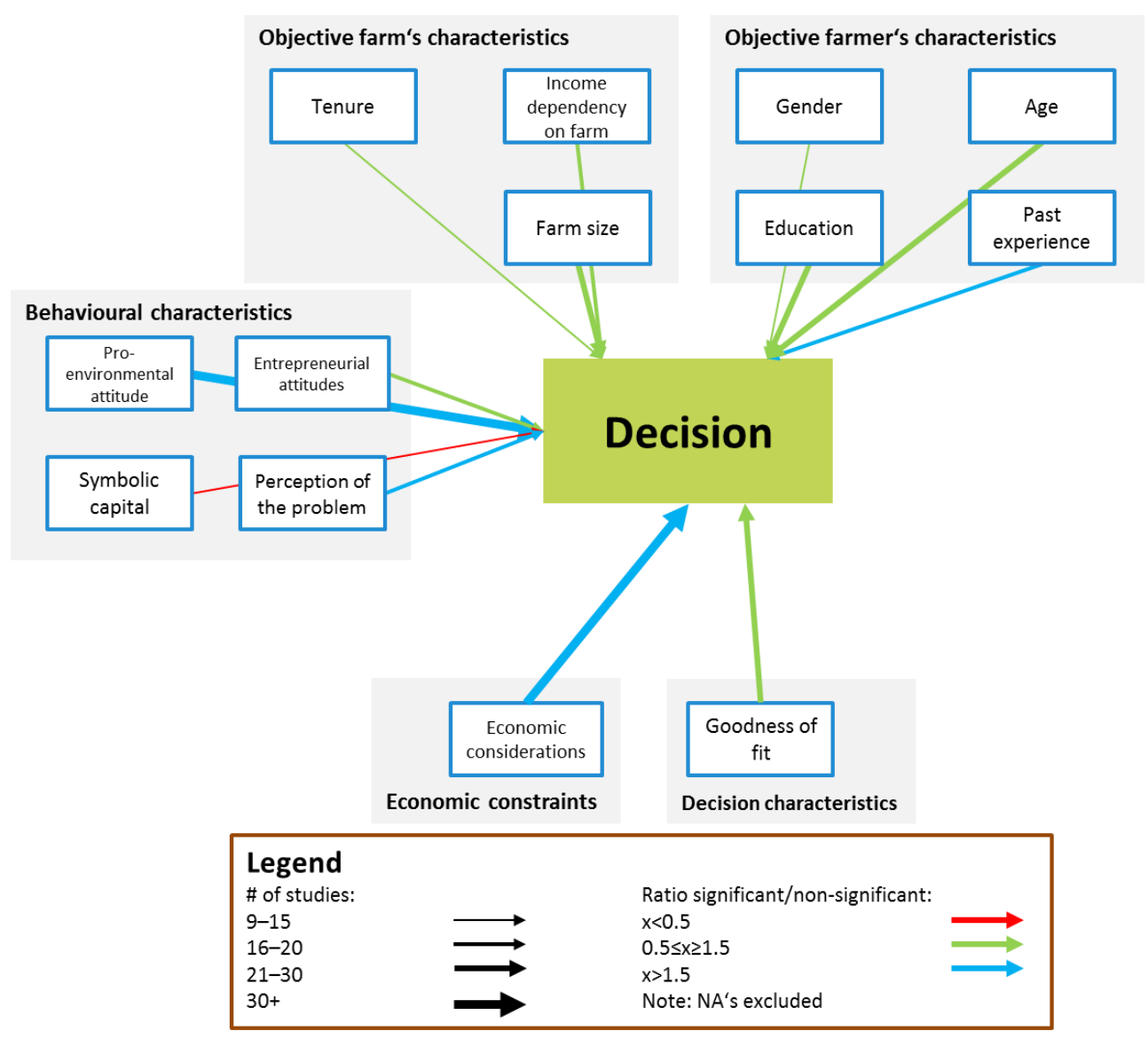

Figure 8. Most frequent factors sorted by conceptual framework categories.

It is immediately recognizable where the research gaps are located. Particularly, no decisioninfluencing factor of the category 'social-institutional environment' has been studied in 10 or more studies, the cut-off number for Figure 8.

The most frequently studied factor is, as already mentioned in the Results section, economic considerations (47 studies). In this broad category, various notions of changes in prices and costs as well as general considerations related to financial restrictions and monetary incentives related to the decision at hand are included. In line with the classic findings by Wilson and Hart [14], economic considerations have a rather strong influence on decision-making across studies, with only two studies finding this factor to be non-significant: Micha et al. [110] found that financial considerations do not influence farmers' willingness to participate in a subsidy scheme for organic vine growing; and in Lamarque et al.'s [59] innovative study of mountain grassland farmers, distance-related costs had no significant influence on their hypothetical decisions. Overall, however, the observation is quite robust across studies: economic considerations have a significant influence on all manner of decisions made by farmers. Given that farmers are, among other things, entrepreneurs, this is not surprising. In fact, it should be more interesting to see what other factors are influential, especially if they can be expected to counteract the effects of economic considerations on farmers' decision-making.

Another frequently studied group of factors was demographic characteristics of farmers, particularly age (29 studies) and education (26 studies). Here, the results are mixed, with similar numbers of significant and non-significant studies. This is very much in line with the results of the excellent study by Burton [18], who provides a number of possible explanations for the seemingly contradictory results across different studies. In contrast, another demographic characteristic — gender—has been studied much less frequently (nine studies); here, too, both significant 
and non-significant effects have been found (four and five times, respectively). While most farmers in Europe are male [124], the proportion of women in the agricultural working force ranges between 30 and 50 percent in most E.U. countries, so if women behave differently than men, as some of the studies analysed here indicate $[86,108,112,121]$, it would be interesting to understand why this is the case, especially given the societal dynamics towards more equal representation of genders across sectors.

Farm size is another quite frequently studied decision-influencing factor (27 studies). We find 14 studies where farm size is a significant determinant (10 non-significant), showing mostly a positive influence on decision to participate in AESs [93,96,97,105,108], to participate in cooperatives [117], impacting pesticides use and pest management [50,51], and the willingness to adopt renewable energies [42]. Although economies of scale and space to try new options might be the key for the implementation of new practices, several studies found no clear link of farm size to factors such as adoption of organic farming [87], renewable energies [42], climate adaptation [67] or local conservation measures [82], cross compliance [39], participation in AES [95,112,116] or in CAP greening [118], or regarding the specialization on hop [120], indicating that farmers' decisions are not merely correlated with or dependent on the available field size in the European context.

Behavioural factors have been studied quite intensively, with pro-environmental attitude and entrepreneurial attitudes being the most frequently studied ones (33 and 17 studies, respectively). Interestingly, the effect of a pro-environmental attitude on decision-making has been consistently significant in most studies, which is a striking result as compared to the well-known attitude-behaviour gap found in studies of consumers [125]. This may be due to the fact that farmers generally have a more direct influence on the environmental effects of their behaviour than consumers; moreover, in the E.U. they are provided with incentives to live up to their attitude (organic farming payments, agri-environmental and climate measures, etc.). On the other hand, Tiffin and Balcombe [87] found no significant effects of pro-environmental attitude, measured by the membership in an environmental organisation, on the adoption of organic farming. Many studies in this context employed qualitative methods, so they do not report significant effects in the statistical sense. However, the qualitatively identified effects of pro-environmental attitude are consistently pointing towards pro-environmental behaviour: it plays a role in the participation in AES $[35,90,106]$, counters incentives to abandon organic farming [84], and has positive influence on more general environmentally friendly on-farm practices $[54,77,83]$.

In contrast to pro-environmental attitude, entrepreneurial attitudes-particularly the classic distinction between productivist and post-productivist attitudes [126], but also more general attitudes towards the goals of farming (e.g., purely profit-oriented versus 'landscape stewardship' versus production of healthy food) - have very different effects on decision-making. Significant influences have been found regarding decisions to participate in AESs in environmentally sensitive areas [92], but against AESs related to field margin or in animal-welfare programmes [97,116]; by tendency in disfavour of adopting organic farming $[87,89]$, yet positively related to adopting renewable energies [42] as well as investing in a hog barn [75]. However, several insignificant results are documented, too, related to participation in country stewardship schemes and in field margin programmes as part of AESs [95,97], to acceptance of cross compliance [39], or on adoption of integrated crop protection or organic farming [86-88]. Further studies investigated the role of entrepreneurial attitudes related to decisions on intercropping [45], manure management [48], switching to biomass production [40], and generally on diversification of business [69]; however, without clear generalisable conclusions. The diversity of the factor makes it difficult to conclude, yet a notable degree of entrepreneurial spirit seems to be a potential trigger of farmers' behaviour to explore and adapt to new practices.

Symbolic capital is a notion developed in the context of Pierre Bourdieu's sociological theory of capital(s) and has been much discussed in the context of farming [29,37,38]; here, we use this term in a broader sense, encompassing any considerations by farmers that are related to how they are perceived by others: be it farmer colleagues, consumers, or the general public. There is partly a strong similarity 
between this factor and 'entrepreneurial attitude', as in both cases one's self-image as a farmer plays a strong role. The results here are mixed, partly because of the large differences in what was measured specifically, from the importance of 'clean fields' [53] to 'farm image' [14], but also the influence of 'symbolic capital', for example on participation in AESs, depends strongly on which type of image is important to the farmer. However, it seems that overall symbolic capital has some influence on farmers' decision-making, though this influence varies depending on context.

One of the few factors with a consistent effect across studies is past experience (usually in the context of participation in AESs): farmers who already once participated in a scheme or measure are more likely to participate in similar schemes or measures in the future. This statistical effect finds strong support and thorough sociological explanation in the recent study by Riley [29], who re-interviewed participants of an older study regarding AES participation after circa 10 years to find that they had grown accustomed to the scheme and developed an understanding for its rationale and an identification with it. However, this of course does not answer the question of how farmers can be incentivised to join such schemes and measures in the first place, i.e., how individual path dependencies may be best overcome [46].

Another rather strong and important factor is 'goodness of fit', both in terms of fit with existing management practices and fit with legal obligations. Particularly, the former dimension has multiple aspects; of course, easily implemented measures are preferred by farmers, as they minimise effort [106]. However, oftentimes the measures discussed in the studies simply did not fit the orientation of the farmers' activities; for instance, in Warren et al.'s [43] study of willingness to introduce short-rotation coppice, an important obstacle was that many interviewed farmers focused on animal husbandry, not arable farming. On the positive side, in Bechini et al.'s [60] study, the incorporation of crop residues to improve soil quality appeared to be attractive where burning of the residues was prohibited, thus restricting the space of alternative options. Overall, it appears that goodness of fit is consistently influential for farmers' decision-making, a result that has some intuitive appeal. This is particularly important for the design of policy instruments meant to incentivise sustainable management practices (see next section).

Institutional economics suggests that property rights are a very important determinant of resource management [127]; therefore, it is often assumed that tenure status is an important factor influencing decision-making behaviour of farmers [22,128]. However, the results in this respect are rather mixed, with significant and non-significant effects found equally frequently. The literature on the relationship between tenure prices and land rents resulting from CAP direct payments demonstrates that the effects of tenure are much more complex than simple economic models suggest [129]; similar complexity can be expected in the context of their influence on farmers' decision-making. Therefore, we can only repeat Prokopy et al.'s [22] 10-year-old call for more research in this area.

There are a number of factors that have been studied only in very few studies each, some of which appear potentially highly relevant and interesting. In what follows, we briefly comment on a few such factors that deserve more research attention as they are potentially relevant for governance:

On-farm (adoption of) technologies: given that precision (or smart) farming is increasingly considered an important option that may help achieve more sustainability in farming generally [130] and in agricultural soil management specifically [8], the lack of insights into how on-farm adoption and use of technologies, both agricultural and general-purpose (for instance broadband internet), interacts with decision-making is bothering and an important research gap. In one of the few studies in this context, Morris et al. [69] found a relationship between use of technologies (decision-support systems, broadband internet, farm website) and diversification of and beyond farm activities.

Advisory services: Knowledge and information are preconditions to action. Surprisingly, we found only a few studies on the role of advisory services. Even more surprising is that we do not find a clear link but again a mixed picture related to the significance of the impact on farmers' decision-making, for example to facilitate best management practices, new ideas, and new technologies $[44,47,70,83,116]$. Bager and Proost [44] illustrate that advice as a voluntary measure to influence farmer behaviour can 
be effective alongside compulsory regulation by supporting farmers in the search and readiness for new technical solutions and through influencing farmers' priorities and attitudes. It is noteworthy that the efficacy is linked to habits of interaction, for example a tradition of strong study groups as found in the Netherlands. Ingram [47] emphasises that group activities with empowerment and reorientation are a more effective form of advice than mere provision of information, while also pointing out that the advisor's motivations and values play a key role. Mills et al. [83] point out that advisory services will be effective only if they cope with the heterogeneity of farmers' beliefs and values. Hence, more research is needed to understand the effective co-creation of credible and trusted partnerships enabling a co-production of knowledge and understanding $[47,83]$.

Bureaucratic load: as agriculture in the E.U. (and most OECD (Organization for Economic Co-Operation and Development) countries) is heavily regulated and farmers are highly dependent on CAP direct and other payments [131], the bureaucratic load can be expected to play a major role in decision-making, particularly with respect to voluntary participation in measures such as AESs or organic farming $[14,84,90,99,100,118]$. Curiously enough, studies of the actual extent of bureaucratic work as part of overall farm-related workload seem to be non-existent; the few available studies of time allocation by farmers focus on allocation between on-farm and off-farm labour [132,133]. Relatedly, there has been little research so far on the attitude of farmers towards their own subsidy-dependence, though some indications can be found scattered in the literature that subsidy-dependence is met with discontent $[69,107]$.

Social capital, social norms, peer orientation: we already discussed above the broad and diverse influence of 'symbolic capital' on farmers' decision-making. A related set of so far understudied factors are social capital, social norms, and peer orientation. These are difficult-to-capture factors that may, however, have large relevance for decision-making. The extent to which farmers have social networks $[73,108,116]$, how open they are to those [95], and the type of norms and how they respond to them [83] are important influences on on-farm decision-making. Particularly, in the face of movements such as community-supported agriculture [134], it is no longer only relationships towards other farmers and advisors that are relevant, but also social interactions with consumers gain increasing importance.

Risk aversion: there is a growing literature on the opportunities to alleviate (downside) risk involved in agricultural practices not only by means of financial instruments but also management practices that increase biodiversity [135-138], and while there are studies on the influence of risk and risk aversion on farmers' decision-making, with rather consistent results indicating that risk plays a large role, there is still much need for further investigation, including specifically in the context of biodiversity-increasing management practices.

One striking result of our literature review is that there are hardly any studies of farmers' decision-making behaviour that can be clearly linked to soil management and soil pressures. This is also reflected in the under-representation of particular decision types. For instance, the already mentioned issue of adoption of technologies, particularly choice of machinery-so crucial in the context of smart farming [130]—is vastly understudied. In our selection of studies, only Foxall's [62] 1979 study of tractor choice was explicitly devoted to this topic. Bukchin and Kerret's [139] recent literature review suggests which 'personal resources' (behavioural characteristics in our nomenclature) influence technology adoption. While the authors transfer these findings to the adoption of 'green technologies' by farmers, there is a need for more empirical research specifically targeting farmers' decision-making in this context. It is striking that decisions for specific machinery have not been examined despite an increasing practitioners' debate on more flexible tools to cater to smaller field owner requirements [8].

Another area that deserves more investigation is climate change adaptation: climate change is increasingly affecting European agriculture, with significant consequences for example in terms of soil moisture $[140,141]$. How European farmers adapt to climate change and what influences their decisions in this context is still a largely open question. Soils and their management play a major role 
in this context [142]. More generally, farmers' willingness to diversify and engage in non-farming activities, to go beyond traditional farming identities exemplified by the figure of 'good farmer' [28], thus overcoming path dependencies, enlarging individual option space, and possibly also contributing to making agricultural landscapes more multifunctional [143] is currently not well-understood.

Inevitably, due to challenges in optimizing the search string for the literature review, some literature might have been missed in our analysis. For instance, Prager and Posthumus [17] include some relevant studies not covered by our review (we thank a reviewer for pointing this out); their overall results, however, are largely consistent with ours.

\section{Implications for Soil Governance}

The main message of the literature corpus reviewed and synthesised above is probably not very surprising: economic constraints are an essential determinant of farmers' decision-making behaviour. However, economic constraints are not all there is, and this is a highly important insight. It means that a sole focus on economic factors in designing soil governance instruments can lead to inefficiencies; if, for instance, an AES provides significant remuneration, but ignores cultural opposition to the thus incentivised practices, it may be necessary to offer an inefficiently high payment in order to overcome cultural barriers and achieve a sufficient coverage by the scheme. However, if the cultural opposition (or other non-economic factors present) is tackled directly in an appropriate way, the cost of the governance instruments need not be inefficiently high. For this, however, there is a general need for information about both economic and non-economic factors that are determinants of farmers' decision-making in terms of their distribution among target populations for policy and governance so that targeted instruments can be designed.

Specifically, in our review, we have identified multiple relevant factors that influence farmers' decision-making alongside prices, (opportunity) costs, and financial incentives. These factors should be taken into account in designing agri-environmental policy instruments both in the context of soils and beyond. Not all of them are equally relevant for governance purposes, of course. For instance, empirical results across studies show the importance of demographic factors [19], but these are a datum that cannot be easily influenced. Knowledge of their importance has mainly the role of informing which farmer groups may be targeted differently and how, but the age structure or gender representation among farmers can hardly be affected by means of agri-environmental policy (though, of course, there are attempts to influence these factors in a more long-term way by means of other types of social and agricultural policy, for example through payments to young farmers within the CAP).

Conversely, the significant influence of pro-environmental attitudes on farmers' decision-making suggests an avenue for fostering sustainable soil management. Although attitudes are not easily influenced, approaches targeting them-for instance, by means of education, information provision, exchange with other farmers (field days etc.) — can be used to support the effect of other types of incentives, including economic instruments. Recent psychological research provides crucial insights into how attitude change is triggered by, for instance, social media and social networks [144]. This research shows, among other things, that the influence of peers ('buzz agents') is large and has already been harnessed in both marketing and public policy.

One important result of our review, particularly in the context of soil management, is the decisiveness of 'goodness of fit'. Soils are highly heterogeneous and multifunctional, which makes generic governance solutions potentially ineffective. Thus, context-specificity and spatial explicitness of instruments are generally required in soil governance. This insight is strengthened by the widespread observation that farmers prefer adopting measures that are consistent with their own status quo activities; understandably, they prefer incremental changes in practices rather than large-scale, uncertain overhauls. This suggests that on top of being context-specific, soil governance instruments should be flexible so as to allow for step-by-step adaptation of practices.

In the previous section, we discussed a number of interesting but understudied factors influencing farmers' decision-making. Three of those appear to be particularly relevant from the point of view of 
(soil) governance. First, there is the role of extension services and agricultural/agronomic advisors. The vast diversity of advisory services available to farmers and the complex interactions between the two groups suggest that their role in facilitating sustainable practices, including sustainable soil management, should be carefully considered $[47,83,145]$. Innovative formats, such as collaborative extension services that bring together farmers with potentially different perspectives (note the link to the above discussion of fostering pro-environmental attitudes), may have particularly large potential in this respect [44], but there is a need for more research into the role of advisory services. Second, many existing agricultural policies lead to a significant bureaucratic load faced by farmers. However, modern technological developments, such as precision farming and the thus generated data, may lower this load if the information currently provided by farmers could be generated, stored, and transmitted (semi-)automatically and with higher precision $[130,146]$. Furthermore, this and the technologies involved may allow us to make soil governance instruments more context-specific and spatially explicit, for instance by overcoming the measurement and attribution barriers that have so far largely prevented the adoption of result-oriented AESs [147,148]. Third and relatedly, use and adoption of technologies is a highly understudied issue, which, however, is highly important against the background of the opportunities offered by precision farming and related technological developments for soil management and governance.

\section{Conclusions}

Effective, efficient, and legitimate natural resource and agri-environmental governance requires a thorough understanding of the natural system in as much as flexibility to adjust rules and (formal) institutional settings to new knowledge. One element to leverage governance is the knowledge of the behavioural characteristics of the involved actor groups. In this paper, we focused on sustainable governance of agricultural soils and on farmers as the group with the most direct relationship to this particular resource. In our synthesising analysis of existing empirical studies of farmers' decision-making, we found that while economic constraints and incentives are very important in this context, other factors also have significant effects. Particularly strong and consistent effects have been found for pro-environmental attitudes, goodness of fit, and past experience. Conversely, we found mixed results for demographic factors and symbolic capital. We also identified a number of interesting yet understudied factors, including adoption of technologies, advisory services, bureaucratic load, risk aversion and social capital, social norms, and peer orientation. These are factors that are potentially highly relevant for soil governance, particularly against the background of recent technological developments, but robust empirical evidence is still missing (though existing studies give hints at the possible effects). From those results we derived implications for governance, which boil down to the main message of the paper, namely that the non-economic factors influencing farmers' decision-making should not be easily brushed aside, as their consideration in combination with economic factors may well improve the efficiency, effectiveness, and legitimacy of soil governance.

Author Contributions: B.B. and S.B. conceptualised the paper. B.B. conducted the review. B.B. wrote most of the paper and S.B. read and commented on the whole text and contributed particularly to Section 5.

Funding: This work was funded by the German Federal Ministry of Education and Research (BMBF) in the framework of the funding measure "Soil as a Sustainable Resource for the Bioeconomy-BonaRes" (grant 031A608A).

Acknowledgments: We would like to thank Victoria Dietze for assistance with the literature search and Lea Siebert for support in the preparation of figures and tables.

Conflicts of Interest: The authors declare no conflict of interest. The founding sponsors had no role in the design of the study; in the collection, analyses, or interpretation of data; in the writing of the manuscript, and in the decision to publish the results. 


\section{Appendix A}

Search term combination:

TITLE: ((decision* OR adoption OR behavio* OR involvement OR participat* OR accept ${ }^{*}$ OR practice* OR willingness* OR preference* OR response*) AND farmer*) AND TOPIC: (("q method*" OR "q-method" OR delphi OR interview* OR "focus group*" OR "group discussion*" OR experiment* OR survey OR participatory OR questionnaire* OR workshop* OR "case stud*") AND (Europ* OR Portug* OR Spain OR Spanish OR France OR French OR Ireland OR Irish OR "United Kingdom" OR Brit* OR Engl* OR Wales OR Welsh OR Scot* OR Belg* OR Dutch OR Netherland* OR Holland OR Swiss OR Switzerland OR German* OR Ital* OR Austria* OR Denmark OR Danish OR Norw* OR Swed* OR Finland OR Finnish OR Icel* OR Poland OR Polish OR Czech OR Slovak* OR Sloven* OR Lithuan* OR Latvi* OR Eston* OR Hungar* OR Croat* OR Serb* OR Bosn* OR Bulgar* OR Romania* OR Moldav* OR Moldova OR Ukrain* OR Belarus* OR Greek OR Greece OR Cypr* OR Malt* OR Macedon* OR Makedon* OR Montenegr* OR Alban* OR Andor* OR Luxemburg* OR Lichtenstein*)).

\section{Appendix B}

Further information from literature review:

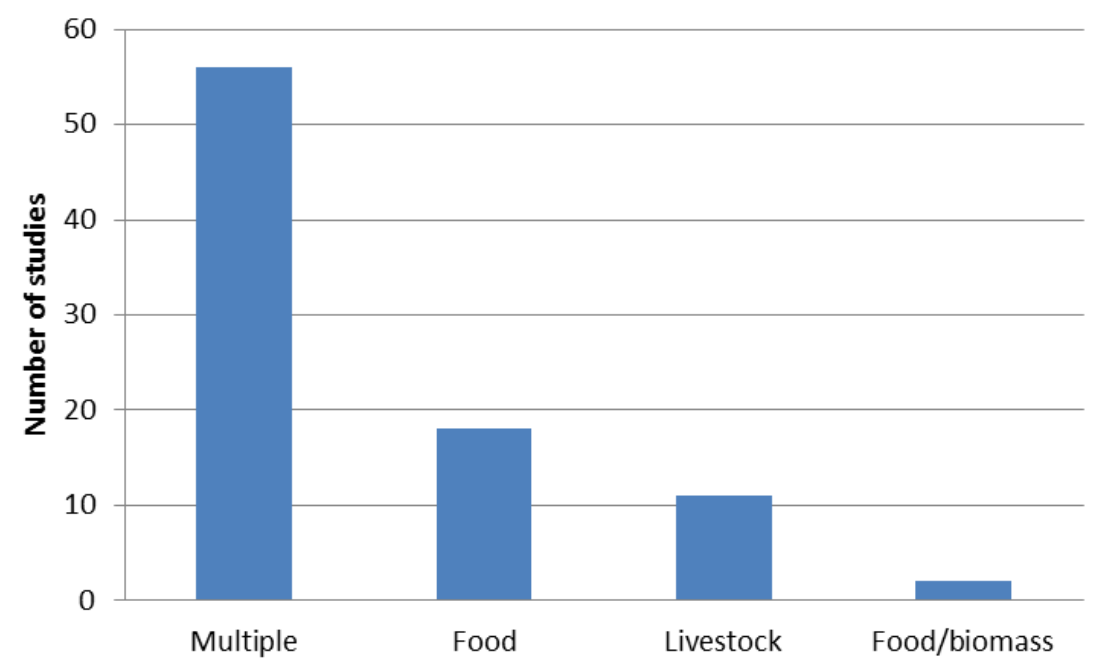

Figure A1. Production systems analysed.

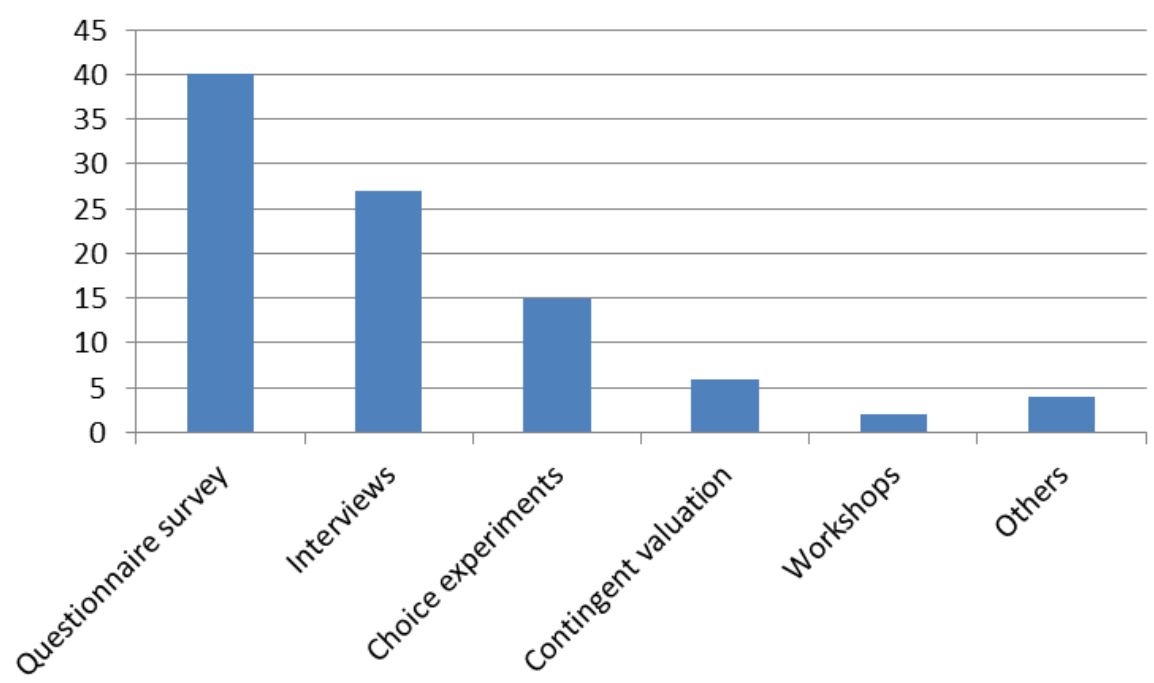

Figure A2. Methods used. 


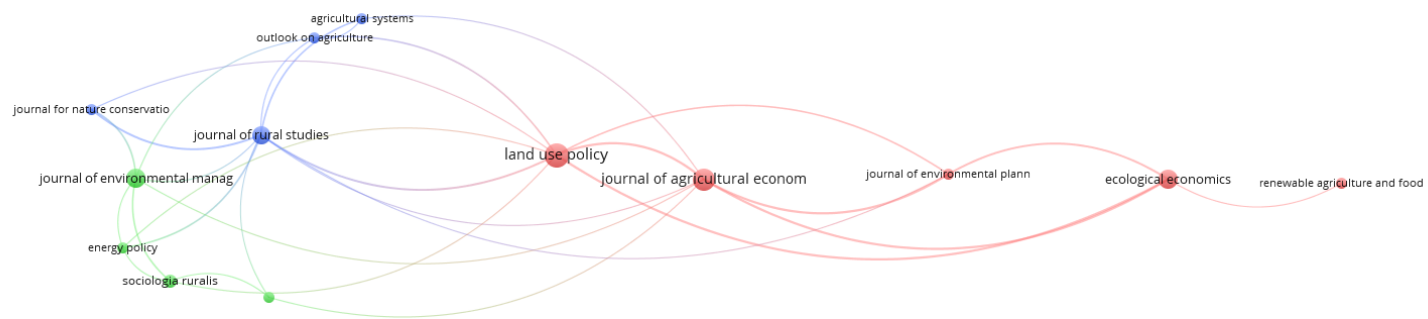

Figure A3. Cross-citations between journals (journals with minimum 2 articles).

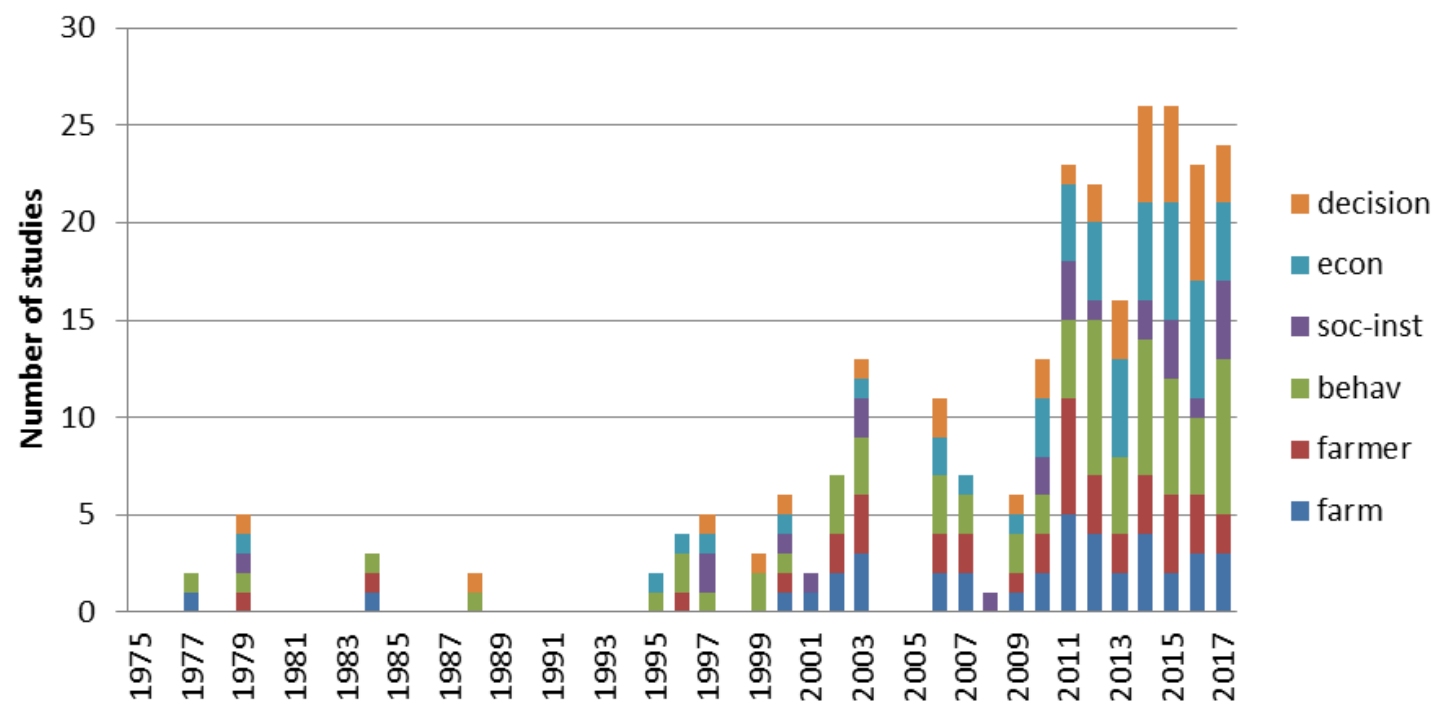

Figure A4. Factors belonging to different conceptual framework categories over time.

Table A1. Methods versus conceptual framework categories.

\begin{tabular}{|c|c|c|c|c|c|c|}
\hline Methods/Categories & Interviews & $\begin{array}{l}\text { Questionnaire } \\
\text { Survey }\end{array}$ & $\begin{array}{c}\text { Choice } \\
\text { Experiments }\end{array}$ & $\begin{array}{l}\text { Contingent } \\
\text { Valuation }\end{array}$ & Workshops & Others \\
\hline Objective characteristics of farm & 9 & 18 & 7 & 5 & 0 & 4 \\
\hline Behavioural characteristics & 19 & 34 & 10 & 5 & 2 & 4 \\
\hline Social-institutional environment & 8 & 12 & 2 & 0 & 0 & 2 \\
\hline Economic constraints & 13 & 21 & 13 & 0 & 1 & 2 \\
\hline
\end{tabular}

\section{References}

1. Adhikari, K.; Hartemink, A.E. Linking soils to ecosystem services-A global review. Geoderma 2016, 262, 101-111. [CrossRef]

2. Dominati, E.J.; Patterson, M.; Mackay, A. A framework for classifying and quantifying the natural capital and ecosystem services of soils. Ecol. Econ. 2010, 69, 1858-1868. [CrossRef]

3. Mirzabaev, A.; Nkonya, E.; von Braun, J. Economics of sustainable land management. Curr. Opin. Environ. Sustain. 2015, 15, 9-19. [CrossRef]

4. Gomiero, T. Soil Degradation, Land Scarcity and Food Security: Reviewing a Complex Challenge. Sustainability 2016, 8, 281. [CrossRef]

5. Juerges, N.; Hansjürgens, B. Soil governance in the transition towards a sustainable bioeconomy-A review. J. Clean. Prod. 2018, 170, 1628-1639. [CrossRef] 
6. Montanarella, L.; Vargas, R. Global governance of soil resources as a necessary condition for sustainable development. Curr. Opin. Environ. Sustain. 2012, 4, 559-564. [CrossRef]

7. Juerges, N.; Hagemann, N.; Bartke, S. A tool to analyse instruments for soil governance: The REEL-framework. J. Environ. Policy Plan. 2018, 1-15. [CrossRef]

8. Techen, A.-K.; Helming, K. Pressures on soil functions from soil management in Germany. A foresight review. Agron. Sustain. Dev. 2017, 37, 64. [CrossRef]

9. Helming, K.; Daedlow, K.; Paul, C.; Techen, A.; Bartke, S.; Bartkowski, B.; Kaiser, D.; Wollschläger, U.; Vogel, H.-J. Managing soil functions for a sustainable bioeconomy-Assessment framework and state of the art. Land Degrad. Dev. 2018. [CrossRef]

10. Vogel, H.-J.; Bartke, S.; Daedlow, K.; Helming, K.; Kögel-Knabner, I.; Lang, B.; Rabot, E.; Russell, D.; Stößel, B.; Weller, U.; et al. A systemic approach for modeling soil functions. Soil 2018, 4, 83-92. [CrossRef]

11. Abson, D.J.; Fischer, J.; Leventon, J.; Newig, J.; Schomerus, T.; Vilsmaier, U.; von Wehrden, H.; Abernethy, P.; Ives, C.D.; Jager, N.W.; et al. Leverage points for sustainability transformation. Ambio 2017, 46, 30-39. [CrossRef] [PubMed]

12. Meadows, D.H. Leverage Points: Places to Intervene in a System; The Sustainability Institute: Hartland, VT, USA, 1999.

13. Turpin, N.; ten Berge, H.; Grignani, C.; Guzmán, G.; Vanderlinden, K.; Steinmann, H.-H.; Siebielec, G.; Spiegel, A.; Perret, E.; Ruysschaert, G.; et al. An assessment of policies affecting Sustainable Soil Management in Europe and selected member states. Land Use Policy 2017, 66, 241-249. [CrossRef]

14. Wilson, G.A.; Hart, K. Financial Imperative or Conservation Concern? EU Farmers' Motivations for Participation in Voluntary Agri-Environmental Schemes. Environ. Plan. A 2000, 32, 2161-2185. [CrossRef]

15. Siebert, R.; Toogood, M.; Knierim, A. Factors Affecting European Farmers' Participation in Biodiversity Policies. Sociol. Rural. 2006, 46, 318-340. [CrossRef]

16. Lastra-Bravo, X.B.; Hubbard, C.; Garrod, G.; Tolón-Becerra, A. What drives farmers' participation in EU agri-environmental schemes? Results from a qualitative meta-analysis. Environ. Sci. Policy 2015, 54, 1-9. [CrossRef]

17. Prager, K.; Posthumus, H. Socio-economic factors influencing farmers: Adoption of soil conservation practices in Europe. In Human Dimensions of Soil and Water Conservation: A Global Perspective; Napier, T.L., Ed.; Nova Science Publishers: New York, NY, USA, 2010; pp. 203-223. ISBN 978-1-61728-957-6.

18. Riley, M. Turning Farmers into Conservationists? Progress and Prospects. Geogr. Compass 2011, 5, 369-389. [CrossRef]

19. Burton, R.J.F. The influence of farmer demographic characteristics on environmental behaviour: A review. J. Environ. Manag. 2014, 135, 19-26. [CrossRef] [PubMed]

20. Liu, T.; Bruins, R.J.F.; Heberling, M.T. Factors Influencing Farmers' Adoption of Best Management Practices: A Review and Synthesis. Sustainability 2018, 10, 432. [CrossRef] [PubMed]

21. Knowler, D.; Bradshaw, B. Farmers' adoption of conservation agriculture: A review and synthesis of recent research. Food Policy 2007, 32, 25-48. [CrossRef]

22. Prokopy, L.S.; Floress, K.; Klotthor-Weinkauf, D.; Baumgart-Getz, A. Determinants of agricultural best management practice adoption: Evidence from the literature. J. Soil Water Conserv. 2008, 63, 300-311. [CrossRef]

23. Baum, C.M.; Gross, C. Sustainability policy as if people mattered: Developing a framework for environmentally significant behavioral change. J. Bioecon. 2017, 19, 53-95. [CrossRef]

24. Bartke, S.; Boekhold, A.E.; Brils, J.; Grimski, D.; Ferber, U.; Gorgon, J.; Guérin, V.; Makeschin, F.; Maring, L.; Nathanail, C.P.; et al. Soil and land use research in Europe: Lessons learned from INSPIRATION bottom-up strategic research agenda setting. Sci. Total Environ. 2018, 622-623, 1408-1416. [CrossRef] [PubMed]

25. Austin, E.; Willock, J.; Deary, I.; Gibson, G.; Dent, J.; Edwards-Jones, G.; Morgan, O.; Grieve, R.; Sutherland, A. Empirical models of farmer behaviour using psychological, social and economic variables. Part I: Linear modelling. Agric. Syst. 1998, 58, 203-224. [CrossRef]

26. Cárdenas, J.C. Human behavior and the use of experiments to understand the agricultural, resource, and environmental challenges of the XXI century. Agric. Econ. 2016, 47, 61-71. [CrossRef]

27. Burton, R.J.F. Reconceptualising the 'behavioural approach' in agricultural studies: A socio-psychological perspective. J. Rural Stud. 2004, 20, 359-371. [CrossRef] 
28. Burton, R.J.F. Seeing Through the 'Good Farmer's' Eyes: Towards Developing an Understanding of the Social Symbolic Value of 'Productivist' Behaviour. Sociol. Rural. 2004, 44, 195-215. [CrossRef]

29. Riley, M. How does longer term participation in agri-environment schemes [re]shape farmers' environmental dispositions and identities? Land Use Policy 2016, 52, 62-75. [CrossRef]

30. Kuehne, G.; Llewellyn, R.; Pannell, D.J.; Wilkinson, R.; Dolling, P.; Ouzman, J.; Ewing, M. Predicting farmer uptake of new agricultural practices: A tool for research, extension and policy. Agric. Syst. 2017, 156, 115-125. [CrossRef]

31. Ajzen, I. The theory of planned behavior. Organ. Behav. Hum. Decis. Process. 1991, 50, 179-211. [CrossRef]

32. Greiner, R.; Gregg, D. Farmers' intrinsic motivations, barriers to the adoption of conservation practices and effectiveness of policy instruments: Empirical evidence from northern Australia. Land Use Policy 2011, 28, 257-265. [CrossRef]

33. Floress, K.; Reimer, A.; Thompson, A.; Burbach, M.; Knutson, C.; Prokopy, L.; Ribaudo, M.; Ulrich-Schad, J. Measuring farmer conservation behaviors: Challenges and best practices. Land Use Policy 2018, 70, 414-418. [CrossRef]

34. Van Eck, N.J.; Waltman, L. Software survey: VOSviewer, a computer program for bibliometric mapping. Scientometrics 2010, 84, 523-538. [CrossRef] [PubMed]

35. Morris, C.; Potter, C. Recruiting the new conservationists: Farmers' adoption of agri-environmental schemes in the U.K. J. Rural Stud. 1995, 11, 51-63. [CrossRef]

36. Van Eck, N.J.; Waltman, L. Citation-based clustering of publications using CitNetExplorer and VOSviewer. Scientometrics 2017, 111, 1053-1070. [CrossRef] [PubMed]

37. Burton, R.J.F.; Kuczera, C.; Schwarz, G. Exploring farmers' cultural resistance to voluntary agri-environmental schemes. Sociol. Rural. 2008, 48, 16-37. [CrossRef]

38. Sutherland, L.-A.; Darnhofer, I. Of organic farmers and 'good farmers': Changing habitus in rural England. J. Rural Stud. 2012, 28, 232-240. [CrossRef]

39. Davies, B.B.; Hodge, I.D. Farmers' Preferences for New Environmental Policy Instruments: Determining the Acceptability of Cross Compliance for Biodiversity Benefits. J. Agric. Econ. 2006, 57, 393-414. [CrossRef]

40. Convery, I.; Robson, D.; Ottitsch, A.; Long, M. The willingness of farmers to engage with bioenergy and woody biomass production: A regional case study from Cumbria. Energy Policy 2012, 40, 293-300. [CrossRef]

41. Reise, C.; Musshoff, O.; Granoszewski, K.; Spiller, A. Which factors influence the expansion of bioenergy? An empirical study of the investment behaviours of German farmers. Ecol. Econ. 2012, 73, 133-141. [CrossRef]

42. Tate, G.; Mbzibain, A.; Ali, S. A comparison of the drivers influencing farmers' adoption of enterprises associated with renewable energy. Energy Policy 2012, 49, 400-409. [CrossRef]

43. Warren, C.R.; Burton, R.; Buchanan, O.; Birnie, R.V. Limited adoption of short rotation coppice: The role of farmers' socio-cultural identity in influencing practice. J. Rural Stud. 2016, 45, 175-183. [CrossRef]

44. Bager, T.; Proost, J. Voluntary Regulation and Farmers' Environmental Behaviour in Denmark and The Netherlands. Sociol. Rural. 1997, 37, 79-96. [CrossRef]

45. Mary, F.; Dupraz, C.; Delannoy, E.; Liagre, F. Incorporating agroforestry practices in the management of walnut plantations in Dauphiné, France: An analysis of farmers' motivations. Agrofor. Syst. 1998, 43, $243-256$. [CrossRef]

46. Macé, K.; Morlon, P.; Munier-Jolain, N.; Quéré, L. Time scales as a factor in decision-making by French farmers on weed management in annual crops. Agric. Syst. 2007, 93, 115-142. [CrossRef]

47. Ingram, J. Agronomist-farmer knowledge encounters: An analysis of knowledge exchange in the context of best management practices in England. Agric. Hum. Values 2008, 25, 405-418. [CrossRef]

48. Barnes, A.P.; Willock, J.; Hall, C.; Toma, L. Farmer perspectives and practices regarding water pollution control programmes in Scotland. Agric. Water Manag. 2009, 96, 1715-1722. [CrossRef]

49. Wright, S.A.L.; Jacobsen, B.H. Combining active farmer involvement with detailed farm data in Denmark: A promising method for achieving water framework directive targets? Water Sci. Technol. 2010, 61, 2625. [CrossRef] [PubMed]

50. Papadopoulou, S.C. Practices of Greek Farmers in the Application of Insecticides and other Crop Protection Chemicals: Individual and Public Health Safety Parameters. Outlook Agric. 2011, 40, 307-312. [CrossRef]

51. Sharma, A.; Bailey, A.; Fraser, I. Technology Adoption and Pest Control Strategies among UK Cereal Farmers: Evidence from Parametric and Nonparametric Count Data Models: Technology Adoption and Pest Control Strategies among UK Cereal Farmers. J. Agric. Econ. 2011, 62, 73-92. [CrossRef] 
52. Morgan-Davies, C.; Waterhouse, T.; Wilson, R. Characterisation of farmers' responses to policy reforms in Scottish hill farming areas. Small Rumin. Res. 2012, 102, 96-107. [CrossRef]

53. Pedersen, A.B.; Nielsen, H.Ø.; Christensen, T.; Hasler, B. Optimising the effect of policy instruments: A study of farmers' decision rationales and how they match the incentives in Danish pesticide policy. J. Environ. Plan. Manag. 2012, 55, 1094-1110. [CrossRef]

54. Barnes, A.P.; McCalman, H.; Buckingham, S.; Thomson, S. Farmer decision-making and risk perceptions towards outwintering cattle. J. Environ. Manag. 2013, 129, 9-17. [CrossRef] [PubMed]

55. Beharry-Borg, N.; Smart, J.C.R.; Termansen, M.; Hubacek, K. Evaluating farmers' likely participation in a payment programme for water quality protection in the UK uplands. Reg. Environ. Change 2013, 13, 633-647. [CrossRef]

56. Karelakis, C.; Abas, Z.; Galanopoulos, K.; Polymeros, K. Positive effects of the Greek economic crisis on livestock farmer behaviour. Agron. Sustain. Dev. 2013, 33, 445-456. [CrossRef]

57. Damalas, C.A.; Koutroubas, S.D. Determinants of farmers' decisions on pesticide use in oriental tobacco: A survey of common practices. Int. J. Pest Manag. 2014, 60, 224-231. [CrossRef]

58. Jaeck, M.; Lifran, R. Farmers' Preferences for Production Practices: A Choice Experiment Study in the Rhone River Delta. J. Agric. Econ. 2014, 65, 112-130. [CrossRef]

59. Lamarque, P.; Meyfroidt, P.; Nettier, B.; Lavorel, S. How ecosystem services knowledge and values influence farmers' decision-making. PLoS ONE 2014, 9, e107572. [CrossRef] [PubMed]

60. Bechini, L.; Costamagna, C.; Zavattaro, L.; Grignani, C.; Bijttebier, J.; Ruysschaert, G. Barriers and drivers towards the incorporation of crop residue in the soil. Analysis of Italian farmers' opinion with the theory of planned behaviour. Ital. J. Agron. 2015, 10, 178. [CrossRef]

61. Macgregor, C.J.; Warren, C.R. Evaluating the Impacts of Nitrate Vulnerable Zones on the Environment and Farmers' Practices: A Scottish Case Study. Scott. Geogr. J. 2016, 132, 1-20. [CrossRef]

62. Foxall, G.R. Farmers' tractor purchase decisions: A study of interpersonal communication in industrial buying behaviour. Eur. J. Mark. 1979, 13, 299-308. [CrossRef]

63. Holloway, L.E.; Ilbery, B.W. Global warming and navy beans: Decision making by farmers and food companies in the U.K. J. Rural Stud. 1997, 13, 343-355. [CrossRef]

64. Pröbstl-Haider, U.; Mostegl, N.M.; Kelemen-Finan, J.; Haider, W.; Formayer, H.; Kantelhardt, J.; Moser, T.; Kapfer, M.; Trenholm, R. Farmers' Preferences for Future Agricultural Land Use under the Consideration of Climate Change. Environ. Manag. 2016, 58, 446-464. [CrossRef] [PubMed]

65. Urquijo, J.; De Stefano, L. Perception of Drought and Local Responses by Farmers: A Perspective from the Jucar River Basin, Spain. Water Resour. Manag. 2016, 30, 577-591. [CrossRef]

66. Li, S.; Juhász-Horváth, L.; Harrison, P.A.; Pintér, L.; Rounsevell, M.D.A. Relating farmer's perceptions of climate change risk to adaptation behaviour in Hungary. J. Environ. Manag. 2017, 185, 21-30. [CrossRef] [PubMed]

67. Woods, B.A.; Nielsen, H.Ø.; Pedersen, A.B.; Kristofersson, D. Farmers' perceptions of climate change and their likely responses in Danish agriculture. Land Use Policy 2017, 65, 109-120. [CrossRef]

68. Hansson, H.; Ferguson, R.; Olofsson, C. Psychological Constructs Underlying Farmers' Decisions to Diversify or Specialise their Businesses - An Application of Theory of Planned Behaviour: Psychological Constructs Underlying Farmers' Decisions to Diversify. J. Agric. Econ. 2012, 63, 465-482. [CrossRef]

69. Morris, W.; Henley, A.; Dowell, D. Farm diversification, entrepreneurship and technology adoption: Analysis of upland farmers in Wales. J. Rural Stud. 2017, 53, 132-143. [CrossRef]

70. Ambrosius, F.H.W.; Hofstede, G.J.; Bock, B.B.; Bokkers, E.A.M.; Beulens, A.J.M. Modelling farmer decision-making: The case of the Dutch pork sector. Br. Food J. 2015, 117, 2582-2597. [CrossRef]

71. Demartini, E.; Gaviglio, A.; Pirani, A. Farmers' motivation and perceived effects of participating in short food supply chains: Evidence from a North Italian survey. Agric. Econ. 2017, 63, 204-216. [CrossRef]

72. Vogel, S. Farmers' Environmental Attitudes and Behavior: A Case Study for Austria. Environ. Behav. 1996, 28, 591-613. [CrossRef]

73. Celio, E.; Flint, C.G.; Schoch, P.; Grêt-Regamey, A. Farmers' perception of their decision-making in relation to policy schemes: A comparison of case studies from Switzerland and the United States. Land Use Policy 2014, 41, 163-171. [CrossRef]

74. Cerri, J.; Mori, E.; Vivarelli, M.; Zaccaroni, M. Are wildlife value orientations useful tools to explain tolerance and illegal killing of wildlife by farmers in response to crop damage? Eur. J. Wildl. Res. 2017, 63. [CrossRef] 
75. Hermann, D.; Mußhoff, O.; Agethen, K. Investment behavior and status quo bias of conventional and organic hog farmers: An experimental approach. Renew. Agric. Food Syst. 2016, 31, 318-329. [CrossRef]

76. Lips, M.; Gazzarin, C.; Telser, H. Job Preferences of Dairy Farmers in Eastern Switzerland: A Discrete Choice Experiment. Ger. J. Agric. Econ. 2016, 65, 254-261.

77. Beedell, J.D.C.; Rehman, T. Explaining farmers' conservation behaviour: Why do farmers behave the way they do? J. Environ. Manag. 1999, 57, 165-176. [CrossRef]

78. Kristensen, S.P.; Thenail, C.; Kristensen, L. Farmers' involvement in landscape activities: An analysis of the relationship between farm location, farm characteristics and landscape changes in two study areas in Jutland, Denmark. J. Environ. Manag. 2001, 61, 301-318. [CrossRef] [PubMed]

79. Busck, A.G. Farmers' Landscape Decisions: Relationships between Farmers' Values and Landscape Practices. Sociol. Rural. 2002, 42, 233-249. [CrossRef]

80. Herzon, I.; Mikk, M. Farmers' perceptions of biodiversity and their willingness to enhance it through agri-environment schemes: A comparative study from Estonia and Finland. J. Nat. Conserv. 2007, 15, 10-25. [CrossRef]

81. Sattler, C.; Nagel, U.J. Factors affecting farmers' acceptance of conservation measures-A case study from north-eastern Germany. Land Use Policy 2010, 27, 70-77. [CrossRef]

82. Lokhorst, A.M.; Staats, H.; van Dijk, J.; van Dijk, E.; de Snoo, G. What's in it for Me? Motivational Differences between Farmers' Subsidised and Non-Subsidised Conservation Practices. Appl. Psychol. 2011, 60, 337-353. [CrossRef]

83. Mills, J.; Gaskell, P.; Ingram, J.; Dwyer, J.; Reed, M.; Short, C. Engaging farmers in environmental management through a better understanding of behaviour. Agric. Hum. Values 2017, 34, 283-299. [CrossRef]

84. Kirner, L.; Vogel, S.; Schneeberger, W. Intended and actual behavior of organic farmers in Austria after a five-year commitment period. Renew. Agric. Food Syst. 2006, 21, 95-105. [CrossRef]

85. Kallas, Z.; Serra, T.; Gil, J.M. Farmers' objectives as determinants of organic farming adoption: The case of Catalonian vineyard production. Agric. Econ. 2010, 41, 409-423. [CrossRef]

86. Mzoughi, N. Farmers adoption of integrated crop protection and organic farming: Do moral and social concerns matter? Ecol. Econ. 2011, 70, 1536-1545. [CrossRef]

87. Tiffin, R.; Balcombe, K. The determinants of technology adoption by UK farmers using Bayesian model averaging: The cases of organic production and computer usage: The determinants of technology adoption by UK farmers. Aust. J. Agric. Resour. Econ. 2011, 55, 579-598. [CrossRef]

88. Mann, S.; Gairing, M. "Loyals" and “Optimizers": Shedding Light on the Decision for or Against Organic Agriculture among Swiss Farmers. J. Agric. Environ. Ethics 2012, 25, 365-376. [CrossRef]

89. Power, E.F.; Kelly, D.L.; Stout, J.C. Impacts of organic and conventional dairy farmer attitude, behaviour and knowledge on farm biodiversity in Ireland. J. Nat. Conserv. 2013, 21, 272-278. [CrossRef]

90. Karali, E.; Brunner, B.; Doherty, R.; Hersperger, A.; Rounsevell, M. Identifying the factors that influence farmer participation in environmental management practices in Switzerland. Hum. Ecol. 2014, 42, 951-963. [CrossRef]

91. Potter, C.; Gasson, R. Farmer participation in voluntary land diversion schemes: Some predictions from a survey. J. Rural Stud. 1988, 4, 365-375. [CrossRef]

92. Wilson, G.A. Farmer environmental attitudes and ESA participation. Geoforum 1996, 27, 115-131. [CrossRef]

93. Vanslembrouck, I.; Huylenbroeck, G.; Verbeke, W. Determinants of the Willingness of Belgian Farmers to Participate in Agri-environmental Measures. J. Agric. Econ. 2002, 53, 489-511. [CrossRef]

94. Walford, N. Agricultural adjustment: Adoption of and adaptation to policy reform measures by large-scale commercial farmers. Land Use Policy 2002, 19, 243-257. [CrossRef]

95. Mathijs, E. Social Capital and Farmers' Willingness to Adopt Countryside Stewardship Schemes. Outlook Agric. 2003, 32, 13-16. [CrossRef]

96. Söderqvist, T. Are farmers prosocial? Determinants of the willingness to participate in a Swedish catchment-based wetland creation programme. Ecol. Econ. 2003, 47, 105-120. [CrossRef]

97. Wossink, G.A.A.; van Wenum, J.H. Biodiversity conservation by farmers: Analysis of actual and contingent participation. Eur. Rev. Agric. Econ. 2003, 30, 461-485. [CrossRef]

98. Hounsome, B.; Edwards, R.T.; Edwards-Jones, G. A note on the effect of farmer mental health on adoption: The case of agri-environment schemes. Agric. Syst. 2006, 91, 229-241. [CrossRef] 
99. Ruto, E.; Garrod, G. Investigating farmers' preferences for the design of agri-environment schemes: A choice experiment approach. J. Environ. Plan. Manag. 2009, 52, 631-647. [CrossRef]

100. Christensen, T.; Pedersen, A.B.; Nielsen, H.O.; Mørkbak, M.R.; Hasler, B.; Denver, S. Determinants of farmers' willingness to participate in subsidy schemes for pesticide-free buffer zones-A choice experiment study. Ecol. Econ. 2011, 70, 1558-1564. [CrossRef]

101. Lapka, M.; Cudlínová, E.; Rikoon, J.S.; Pělucha, M.; Kvetoň, V. Rural development in the context of agricultural "green" subsidies: Czech farmers' responses. Agric. Econ. 2011, 57, 259-271. [CrossRef]

102. Broch, S.W.; Vedel, S.E. Using choice experiments to investigate the policy relevance of heterogeneity in farmer agri-environmental contract preferences. Environ. Resour. Econ. 2012, 51, 561-581. [CrossRef]

103. Buckley, C.; Hynes, S.; Mechan, S. Supply of an ecosystem service-Farmers' willingness to adopt riparian buffer zones in agricultural catchments. Environ. Sci. Policy 2012, 24, 101-109. [CrossRef]

104. McKenzie, A.J.; Emery, S.B.; Franks, J.R.; Whittingham, M.J. FORUM: Landscape-scale conservation: Collaborative agri-environment schemes could benefit both biodiversity and ecosystem services, but will farmers be willing to participate? J. Appl. Ecol. 2013, 50, 1274-1280. [CrossRef]

105. Schroeder, L.A.; Isselstein, J.; Chaplin, S.; Peel, S. Agri-environment schemes: Farmers' acceptance and perception of potential 'Payment by Results' in grassland-A case study in England. Land Use Policy 2013, 32, 134-144. [CrossRef]

106. Van Herzele, A.; Gobin, A.; Van Gossum, P.; Acosta, L.; Waas, T.; Dendoncker, N.; Henry de Frahan, B. Effort for money? Farmers' rationale for participation in agri-environment measures with different implementation complexity. J. Environ. Manag. 2013, 131, 110-120. [CrossRef] [PubMed]

107. Wynne-Jones, S. Ecosystem Service Delivery in Wales: Evaluating Farmers' Engagement and Willingness to Participate. J. Environ. Policy Plan. 2013, 15, 493-511. [CrossRef]

108. Alló, M.; Loureiro, M.L.; Iglesias, E. Farmers' Preferences and Social Capital Regarding Agri-environmental Schemes to Protect Birds. J. Agric. Econ. 2015, 66, 672-689. [CrossRef]

109. Lienhoop, N.; Brouwer, R. Agri-environmental policy valuation: Farmers' contract design preferences for afforestation schemes. Land Use Policy 2015, 42, 568-577. [CrossRef]

110. Micha, E.; Areal, F.J.; Tranter, R.B.; Bailey, A.P. Uptake of agri-environmental schemes in the Less-Favoured Areas of Greece: The role of corruption and farmers' responses to the financial crisis. Land Use Policy 2015, 48, 144-157. [CrossRef]

111. Villanueva, A.J.; Gómez-Limón, J.A.; Arriaza, M.; Rodríguez-Entrena, M. The design of agri-environmental schemes: Farmers' preferences in southern Spain. Land Use Policy 2015, 46, 142-154. [CrossRef]

112. Franzén, F.; Dinnétz, P.; Hammer, M. Factors affecting farmers' willingness to participate in eutrophication mitigation-A case study of preferences for wetland creation in Sweden. Ecol. Econ. 2016, 130, 8-15. [CrossRef]

113. Sardaro, R.; Girone, S.; Acciani, C.; Bozzo, F.; Petrontino, A.; Fucilli, V. Agro-biodiversity of Mediterranean crops: farmers' preferences in support of a conservation programme for olive landraces. Biol. Conserv. 2016, 201, 210-219. [CrossRef]

114. De Krom, M.P.M.M. Farmer participation in agri-environmental schemes: Regionalisation and the role of bridging social capital. Land Use Policy 2017, 60, 352-361. [CrossRef]

115. Josefsson, J.; Lokhorst, A.M.; Pärt, T.; Berg, Å.; Eggers, S. Effects of a coordinated farmland bird conservation project on farmers' intentions to implement nature conservation practices-Evidence from the Swedish Volunteer \& Farmer Alliance. J. Environ. Manag. 2017, 187, 8-15. [CrossRef]

116. Schreiner, J.A.; Hess, S. The Role of Non-Use Values in Dairy Farmers' Willingness to Accept a Farm Animal Welfare Programme. J. Agric. Econ. 2017, 68, 553-578. [CrossRef]

117. Gasson, R. Farmers' participation in cooperative activities. Sociol. Rural. 1977, 17, 107-123. [CrossRef]

118. Schulz, N.; Breustedt, G.; Latacz-Lohmann, U. Assessing Farmers' Willingness to Accept “Greening”: Insights from a Discrete Choice Experiment in Germany. J. Agric. Econ. 2014, 65, 26-48. [CrossRef]

119. Van Winsen, F.; de Mey, Y.; Lauwers, L.; van Passel, S.; Vancauteren, M.; Wauters, E. Determinants of risk behaviour: Effects of perceived risks and risk attitude on farmer's adoption of risk management strategies. J. Risk Res. 2016, 19, 56-78. [CrossRef]

120. Ilbery, B.W. Agricultural specialization and farmer decision behaviour: A case study of hop farming in the West Midlands. Tijdschr. Econ. Soc. Geogr. 1984, 75, 329-334. [CrossRef] 
121. Menegaki, A.N.; Hanley, N.; Tsagarakis, K.P. The social acceptability and valuation of recycled water in Crete: A study of consumers' and farmers' attitudes. Ecol. Econ. 2007, 62, 7-18. [CrossRef]

122. Bakopoulou, S.; Polyzos, S.; Kungolos, A. Investigation of farmers' willingness to pay for using recycled water for irrigation in Thessaly region, Greece. Desalination 2010, 250, 329-334. [CrossRef]

123. Giannoccaro, G.; Berbel, J. Influence of the Common Agricultural Policy on the farmer's intended decision on water use. Span. J. Agric. Res. 2011, 9, 1021-1034. [CrossRef]

124. Eurostat. Farmers in the EU-statistics. Statistics Explained. Available online: http:/ / ec.europa.eu/eurostat/ statistics-explained/index.php/Farmers_in_the_EU_-_statistics\#Socio-demographic_characteristics (accessed on 15 May 2018).

125. Vermeir, I.; Verbeke, W. Sustainable Food Consumption: Exploring the Consumer "Attitude-Behavioral Intention" Gap. J. Agric. Environ. Ethics 2006, 19, 169-194. [CrossRef]

126. Walford, N. Productivism is allegedly dead, long live productivism. Evidence of continued productivist attitudes and decision-making in South-East England. J. Rural Stud. 2003, 19, 491-502. [CrossRef]

127. Schlager, E.; Ostrom, E. Property-rights regimes and natural resources: A conceptual analysis. Land Econ. 1992, 68, 249-262. [CrossRef]

128. Soule, M.J.; Tegene, A.; Wiebe, K.D. Land Tenure and the Adoption of Conservation Practices. Am. J. Agric. Econ. 2000, 82, 993-1005. [CrossRef]

129. Graubner, M. Lost in space? The effect of direct payments on land rental prices. Eur. Rev. Agric. Econ. 2018, 45, 143-171. [CrossRef]

130. Walter, A.; Finger, R.; Huber, R.; Buchmann, N. Opinion: Smart farming is key to developing sustainable agriculture. Proc. Natl. Acad. Sci. USA 2017, 114, 6148-6150. [CrossRef] [PubMed]

131. Pe'er, G.; Lakner, S.; Müller, R.; Passoni, G.; Bontzorlos, V.; Clough, D.; Moreira, F.; Azam, C.; Berger, J.; Bezak, P.; et al. Is the CAP Fit for Purpose? An Evidence-Based Fitness Check Assessment; German Centre for Integrative Biodiversity Research (iDiv): Leipzig, Germany, 2017.

132. Howley, P.; Dillon, E.; Hennessy, T. It's not all about the money: Understanding farmers' labor allocation choices. Agric. Hum. Values 2014, 31, 261-271. [CrossRef]

133. Kimhi, A. Farmers' time allocation between farm work and off-farm work and the importance of unobserved group effects: Evidence from Israeli cooperatives. Agric. Econ. 1996, 14, 135-142. [CrossRef]

134. Brown, C.; Miller, S. The Impacts of Local Markets: A Review of Research on Farmers Markets and Community Supported Agriculture (CSA). Am. J. Agric. Econ. 2008, 90, 1298-1302. [CrossRef]

135. Finger, R.; Buchmann, N. An ecological economic assessment of risk-reducing effects of species diversity in managed grasslands. Ecol. Econ. 2015, 110, 89-97. [CrossRef]

136. Baumgärtner, S.; Quaas, M.F. Managing increasing environmental risks through agrobiodiversity and agrienvironmental policies. Agric. Econ. 2010, 41, 483-496. [CrossRef]

137. Quaas, M.F.; Baumgärtner, S. Natural vs. financial insurance in the management of public-good ecosystems. Ecol. Econ. 2008, 65, 397-406. [CrossRef]

138. Pascual, U.; Termansen, M.; Hedlund, K.; Brussaard, L.; Faber, J.H.; Foudi, S.; Lemanceau, P.; Jørgensen, S.L. On the value of soil biodiversity and ecosystem services. Ecosyst. Serv. 2015, 15, 11-18. [CrossRef]

139. Bukchin, S.; Kerret, D. Food for Hope: The Role of Personal Resources in Farmers' Adoption of Green Technology. Sustainability 2018, 10, 1615. [CrossRef]

140. Samaniego, L.; Thober, S.; Kumar, R.; Wanders, N.; Rakovec, O.; Pan, M.; Zink, M.; Sheffield, J.; Wood, E.F.; Marx, A. Anthropogenic warming exacerbates European soil moisture droughts. Nat. Clim. Change 2018, 8, 421-426. [CrossRef]

141. Peichl, M.; Thober, S.; Meyer, V.; Samaniego, L. The effect of soil moisture anomalies on maize yield in Germany. Nat. Hazards Earth Syst. Sci. 2018, 18, 889-906. [CrossRef]

142. Sidibé, Y.; Foudi, S.; Pascual, U.; Termansen, M. Adaptation to Climate Change in Rainfed Agriculture in the Global South: Soil Biodiversity as Natural Insurance. Ecol. Econ. 2018, 146, 588-596. [CrossRef]

143. Fischer, J.; Meacham, M.; Queiroz, C. A plea for multifunctional landscapes. Front. Ecol. Environ. 2017, 15, 59. [CrossRef]

144. Albarracin, D.; Shavitt, S. Attitudes and Attitude Change. Annu. Rev. Psychol. 2018, 69, 299-327. [CrossRef] [PubMed] 
145. Ingram, J.; Mills, J. Are advisory services 'fit for purpose' to support sustainable soil management? A review of advisory capacity in Europe. In Proceedings of the BONARES Conference 2018-Soil as a Sustainable Resource, Berlin, Germany, 26-28 February 2018.

146. Wolfert, S.; Ge, L.; Verdouw, C.; Bogaardt, M.-J. Big Data in Smart Farming-A review. Agric. Syst. 2017, 153, 69-80. [CrossRef]

147. Matzdorf, B.; Lorenz, J. How cost-effective are result-oriented agri-environmental measures?-An empirical analysis in Germany. Land Use Policy 2010, 27, 535-544. [CrossRef]

148. Herzon, I.; Birge, T.; Allen, B.; Povellato, A.; Vanni, F.; Hart, K.; Radley, G.; Tucker, G.; Keenleyside, C.; Oppermann, R.; et al. Time to look for evidence: Results-based approach to biodiversity conservation on farmland in Europe. Land Use Policy 2018, 71, 347-354. [CrossRef]

2018 by the authors. Licensee MDPI, Basel, Switzerland. This article is an open access article distributed under the terms and conditions of the Creative Commons Attribution (CC BY) license (http:// creativecommons.org/licenses/by/4.0/). 